\title{
Trade cooperation in light of the forces that are currently re-shaping international business
}

\begin{abstract}
In this research work, Author focus on the analysis trade cooperation in light of the forces that are currently re-shaping international business. Accordance to the foreign trade policy theory further trade liberalisation and improved framework policies would increase trade and promote growth. It must be emphasized that openess to trade is associated with higher incomes and growth and there are the need for new approaches to trade cooperation. What indicates the importance and innovativeness of the research is the presentation of the new models of the foreign trade policy and trade interests. First of all it must underline that in the new theoretical terms in the demand for trade policy very important is factor specificity. The low specificity of factors means that factor returns are equalized throughout a region's economy. On the other hand some factors are stuck in their present uses; therefore, factor returns are not equalized throughout a region's economy, but are industry specific. The main objective of the research task is to give a comprehensive analysis of current trends in foreign trade theory and policy and in particulary the models of foreign trade policy, trade interests indicated by export orientation and import sensitivity, foreign trade policy in different types of authoritarian regimes, protectionistic pressures in different political system, the level of protectionistic pressures, the variation in the foreign trade policy among states, the liberalisation of China foreign trade policy and their effects, the tendencies to international trade liberalisation and the problem of environmental protection, and the tendencies to bilateralism in the foreign trade policy. It should be stressed that free trade in itself is not responsible for economic growth, but more significant are the determining macroeconomic stability and increasing investment.
\end{abstract}

Key words: foreign trade policy, public choice, liberalism, protectionism, autoritarian regimes, bilateralism

\section{Introduction}

t must be emphasized that there are the need for new approaches to trade cooperation in light of the forces that are currently re-shaping international business. It suggests that the multilateral trading system will need to adjust to developments in trade and in the trading environment. The key of trade developments within the broader socio-economic context is especially the rise of global supply chains, the general shift of trade power away from the West towards Asia and espeially to China. A long-termed stability of China depends however on the fast economic growth, which is possible only when this country will be a partner able to play global roles. The question raised is whether the West will see China's rise as an opportunity for cooperation or for conflict.

The international trade in the beginnig of the XXI century has been strongly affected by the force of the economic crisis. The changes are evident in the growing importance of international trade to national economies and to domestic groups within those econo- 
mies, in the closer linkages between trade and other international issues. Realistic point is important trends in the global trade regime during the economic crisis. The growing interdependence and the decline of USA trade hegemony have led to increased competitivness and greater temptations to resort to strategic trade policy.

\section{Materials and Methods}

In the article it presents the contemporary models of foreign trade policy, trade interests indicated by export orientation and import sensitivity, foreign trade policy in different types of authoritarian regimes, protectionistic pressures in different political system, the level of protectionistic pressures, the variation in the foreign trade policy among states, the liberalisation of China foreign trade policy and their effects, the tendencies to foreign trade liberalisation and the problem of natural environment potection, and the tendencies to bilateralism in the foreign trade policy. The general theoretical approach will be of broad interest to economists interested in international questions as well as to political scientists. The main method applied in this research was a method of scientific study. It was used the instutional method, comparative method, the documentation method and statistical methods. Additionally, it used also, the methods of deductive and inductive forecasting.

\section{Discussion}

\section{The contemporary models of foreign trade policy}

Traditionally, political economy models of trade policy have tendend to focus on the demand for protection, with factor endowments driving political reactions to exposure to international trade. Such model simply assumed that adversely affected economic agents would organize to seek protection, which would be afforded to them by their elected representatives in the political system. The supply side for trade policy (Jones, 2015) was either ignored or underspecified in most models (Thies, Porche, 2007, p. 172).

In the foreign trade policy theory interesting are the reviews of Alt et al. (1996) and Nelson (1988) about the demand for trade policy in terms of the theoretical importance of factor specificity (Alt, Frieden, Gilligan, Rodrik, Rogowski, 1996, p. 695; Nelson, 1988, p. 806). Factor specificity refers to the ease with which factors (land, labor, and capital) can move from one sector to another in an economy. The two dominant approaches to explaining the demand side of trade policy used radically differeent assumptions about the specificity of factors. The Heckscher-Ohlin model, used by Rogowski (1989) in his seminal contribution "Commers and Coalitions," assumes very low-factor specificity (Rogowski, 1989). The low specificity of factors means that factor returns are equalized throughout a region's economy. Producers should export goods that intensively use their abundant factors and import goods that intensively use their scarce factors, with the result that owners of abundant factors will favor free trade and owners of scarce 
factors will favor protectionisme. Trade policy coalitions will therefore be organized along factor or class lines. On the other hand, the Ricardo-Viner assumes that some factors are stuck in their present uses; therefore, factor returns are not equalized throughout a region's economy, but are industry specific. Trade policy coalitions should form along the lines of exporting versus import-competing industries.

Neither of these models explains how preferences over trade policies are actually translated into political action (Alt, Frieden, Gilligan, Rodrik, Rogowski, 1996, p. 695). In a discussion of the endogenous tariff literature, Nelson (1988) notes that the mobility costs of the specific-factors model may be a result of productivity differentials, labor union activity, or individual preferences for membership in a given geografic area, industry, or firm (i.e., some form of solidarity) (Nelson, 1988, p. 806). In all of these cases, one can derive a link to preferences for tariff policy, "but without additional information on why the specific-factor model is chosen, it does not tell us much about political organisation."

Alt et al. (1996) suggest that one can begin to understand this process by assuming that rational individuals make cost/benefit calculations (Alt, Frieden, Gilligan, Rodrik, Rogowski, 1996, p. 695). The Heckscher-Ohlin and Ricardo-Viner models tell us the benefits that individuals hope to recive, but the costs of collective action also intervene as they organize to achive those benefits in the political system. Olson (1985) argued that small groups with specialized interests are easier to organize and more effective in securing economic rents than large groups with diffuse interests (Olson, 1985, pp. 928-937). Small groups are better able to control free riders than large groups, and groups with specific or homogenous interests can more easily coordinate and target their activities than groups with diffuse or heterogenous interests. This approach is thought to explain the success of agricultural producer groups in developed countries in organizing for protection as well as the inability of agricultural producer group to organize in developing countries (Anderson, 1995, pp. 401-423; Coleman, 1998, pp. 632-651; Olson, 1985, pp. 928-937; Olson, 1986; Sheingate, 2001; Eagleton-Pierce, 2013).

However, Nelson (1988) points out that we should not assume that organized interests will be equally responsive to all issues (Nelson, 1988, p. 807). Institutionalized interaction among actors may help to explain systematic patterns of action, espacially as institutions created for specific historical purposes may outlive those purposes. Alt et al. (1996) suggest that if a particular group has paid the fixed costs of establishing collective action and developed well-worn channels of acces to public officials, it may defend its trade policy preferences even when the stakes are low because the marginal costs of action are low (Alt, Frieden, Gilligan, Rodrik, Rogowski, 1996, p. 696). It may be the case that "a much more affected but inchoate group does nothing because the start-up costs of organization are too daunting." Past strength of an organization should therefore be an important intervening variable predicting group action on trade policy. Further, as Nelson (1988) argues, once these institutions exist, supply-side interventions may also affect their usefulness as some are deemed legitimate or illegitimate aggregators of interest (Nelson, 1988, p. 807). Thus, we must examine the way in which economic institutions and political institutions interact. Most economic models simply assume that a model of the economy is a model of the demand side for trade policy, but Nelson (1988) suggests that we must elaborate the mechanismes by which demand is articulated to the suppliers 
of trade policy (Nelson, 1988, p. 810). For a good overwiew of this argument, especially as it pertains to agriculture (Thies, Porche, 2007, p. 172; Eagleton-Pierce, 2013).

If the political systems rewards small sectoral groups, than individuals will not pay the costs of organizing large intersectoral coalitions. If the political system rewards large mass movements (i.e., majoritarianism), than individuals will have to pay the costs of organizing large intersectoral coalitions in order to achive any benefits. Collective action costs and political institutions are interactive with factor specifity. They suggest that Rogowski's (1989) Heckscher-Ohlin framework requires low factor specifity, low collective action costs, and domestic political institutions that favor mass movements (Rogowski, 1989). The Ricardo-Viner framework used by the endogenous tariff literature requires that factors are specific, collection action costs are high, and institutions are less majoritarian, with changes in any of these three variables also affecting the typ of coalitions that form.

In the state as a rational dictator model, the state may be seen as either pursuing "good government" goals along a social welfare function or intervening in the economy for their own self- interested model of the state views politicians as offering preferential trade policy to economic actors in exchange for political support (Magee, Brock, Young, 1989; Grossman, Helpman, 1984, pp. 833-850). On the other hand, pluralist theory typically view the state as a neutral aggregator of demands from groups in society. The supply of trade policy is then determined by the balance of power on any given issue. The supply side of trade policy (Jones, 2015) is relatively undeveloped theoretically, and yet a crucial part of the equation. A variety of different characteristics of the political system are posited to affect the supply of trade protectionism, such as politicians incentives to cultivate personal votes, the size of electoral districts, party fragmentation, federalism, presidential versus parliamentary systems, and so on (Nielson, 2003, pp. 407-491; Rodrik, 1995; Rogowski, 1987, pp. 203-222; Rogowski, 1987, pp. 1121-1137).

On a theoretical level, understanding the choice of trade policies in countries is very important. A survey of economists in 1984 suggested that one of the few things they agreed on was that, under most conditions, tariffs, and quotas reduce the general welfare (Frey, 1984, pp. 986-994). The stubbornness of protectionism in the face of international and academic pressure against it has led economists to seek explanations. These explanations range from the simple ignorance of politicians to arguments about the rationality of protection for "infant industries" and "optimal tariff levels" in developing states. Faced eith this frustrating question, scholars have increasingly turned to political answers in order to explain the choice of what would seem to be an "irrational" policy (Frey, 1984, pp. 199-223; Nau, 1989; Nelson, 1988, pp. 796-837).

\section{Trade interests indicated by export orientation and import sensitivity}

The evidence considered provides substantial support for the argument that the trade interests of their constituents, as indicated by export orientation and import sensitivity of their district, influence policymakers' behaviour on political and security issues. These effects are mediated by party and the heterogenity of constituency and are consistent in both roll-call voting and sposorship activity (Kleinberg, Fordham, 
2013, p. 615). Export orientation appears to be somewhat more important than import sensitivity. Both have substantively meaningful effects on sponsorships, but only export orientation is a statistically significant predictor of roll-call voting (Kleinberg, Fordham, 2013, p. 615).

About the liberal argument it is important to underline that trade reduces international conflict and promotes cooperative foreign policies. The first is that the benefits of international trade indeed appear to influence policymakers' attitudes toward trading partners as the liberal argument suggests (Kleinberg, Fordham, 2013, p. 615). These results complement similar effects it can found in surveys of mass public (Kleinberg, Fordham, 2010; Fordham, Kleinberg, 2011).

The second conclusion is an important qualification to the liberal argument, though not one that is at odds with its underlying logic. Because the aggregate benefits of international trade are not shared equally within the trading states, trade's political effects do not apply to everyone. The fact what some people can expect their income to decline as a result of international trade is critically important for whether is actually reduces conflict between trading partners. These people could contribute to demands for a less-cooperative foreign policy as well as for trade protection. In priciple, the winners in the trading relationship should be able to remove this motive by compensating the losers out of the aggregate benefits of trade. In practice, such compensation is not always offered (Kleinberg, Fordham, 2013, p. 615).

It is important to underline that legislative measures do not always have immediate effect on national policy (Kleinberg, Fordham, 2013, p. 615). For exemple the East Asia Security Act did not became law, though it had substantial support. Many of the other measures have a large number of cosponsors. The executive branch can and does block many such measures that would harm for exemple US relations with China. These legislative measures are still consequential. The cost of blocking them rises with the number of members who support them. Facing an unfavorable domestic political environment, the executive might set aside cooperative measures that it would otherwise have proposed. Moreover, for exemple the Chinese government takes not of hostile proposals in Congress, so they may affect political relations even if they not become national policy (Kleinberg, Fordham, 2013, p. 615).

A bilateral relationship, are also very important. This relationship is cleary unusual in some key respects. Relations USA with China are far more uncertain than relations with other major American trading partners, many of whom are longstanding democratic allies. Those harmed by trade with this other states would have difficulty convincing other Americans to view them as potential enemies. However, it does not follow that trade can have not effect on these relationships. That are points of tension and disagreement even among the closest of allies. Those who lose from trade might support less cooperative positions on these differences, perhaps using them as the basis for limiting the trading relationship. The 1996 Helms-Burton Act's effort to force European firms to adhere to American sanctions against Cuba is on possible example of such a measure (Kleinberg, Fordham, 2013, p. 615). Special research would be nesessary to test the domestic political effects on trade in the context of friendlier international relationships, but there is not reason to expect these effects to be confined to the relations between the United States and China (Kleinberg, Fordham, 2013, p. 615). 
Interesting question is, which authoritarian regimes are most politically liberal? Among the authoritarian regime types often identified in the literature, multiparty, and to a lesser extent single-party, regimes will tend to have the largest selectorates. Therefore it argue that multiparty and single-party authoritarian regimes will have more open trade policies than other authoritarian regime types, other things equal. More specifically in the Wright-Geddes data (Wright, 2008a; 2008b; Geddes, 1999), the coding is divided into four categories: single-party, military, monarchist, and personal regimes (Hankla, Kuthy, 2013, p. 495). In the case using this data, it can expect that single party regimes will tend to have more liberal trade policies than other authoritarian regime types. For the test using the Hadenius and Teorell data (Hadenius, Teorell, 2007, pp. 143-156), it can expect that multiparty regimes will tend to have more liberal trade policies in comparison with any of the other four regime types (single-party, military, monarchy, and personal regimes) (Hankla, Kuthy, 2013, p. 495).

The second component institutionalization argument is that regime stability encourages free trade policies in authoritarian systems. More institutionalized autocratic regimes are better able to co-opt dissent and should therefore tend to enjoy longer and more stable tenures. As a regime's stability increases, the time horizons, in turn produce powerful incentives to enact policies that will benefit the country's economy in the long run rather than just shore up support for the leadership in the immediate future. As Olson (1993) has argued even kleptocratic dictators have good reason to maintain the health of their national economies, if only to provide sources of future loot. By contrast, authoritarian leaders sitting a top unstable regimes and fearing removal will not be thinking about the long-term future. Instead their focus will be providing immediate benefits to their supporters in order to remain in power. As a consequence, the leaders of more stable autocratic regimes will be more likely to provide the public good of free trade, while those whose hold on power is precarious will tend to rely on particularistic goods such as protectionism to keep their winning coalition intact (Hankla, Kuthy, 2013, p. 495).

This argument follows the logic presented by Hankla (2006) on time horizons and trade policy decisions in democracies, expect that it concerned here with authoritarian stability rather than electoral volatility. It is also similar to the argument developed by Wright (2008b) linking long time horizons in authoritarian regimes to the effectiveness of foreign aid (a rare piece of research exploring the policy implications of regime stability under dictatorship). Indeed, the prospects for stability to matter are perhaps greater in authoritarian regimes than in democracies, because for ruling groups in the regimes, losing power often results in death or imprisonment. Therefore, the pressure for protectionism in an attempt to gain short-term support in new unstable regimes is likely to be even grater for authoritarian governments than for those in a democracy. Additionally, truly stable authoritarian regimes tend to have individual leaders with very long time horizons (far beyond those of stable democratic leaders), providing them with stronger incentives to choose policies, like free trade, that may contribute to long-run economic growth (Hankla, Kuthy, 2013, p. 495).

It is important underline that authoritarian regimes like China do not behave similarly to one another with regard to their trade policies and that it is mistake to consider such 
regimes as identical (Hankla, Kuthy, 2013, p. 503). Using the Hadenius and Teorell data (Hadenius, Teorell, 2007, pp. 143-156), it find that multiparty regimes have significantly lower levels of trade protectionism than single-party autocracies, monarchies, non party regimes, and military juntas. As a robustness check, it also find significant support for Wright - Geddes data (Wright, 2008a; 2008b; Geddes, 1999). In addition it find evidence using both the Hadenius and Teorell and Wright-Geddes for conclusion that more stable regimes as China will, on average, have more liberal trade policies. The effect of individual leader duration appears weaker, but there is some limited evidence of its importance (Hankla, Kuthy, 2013, p. 503).

Scholary unterstanding of the behavior of authoritarian regimes will need to be tied closely to an examination ot their institution and institutionalization. Perhaps the most fruitful arena for future research will be to focus on the specific preferences of selectorates composition and policy outcomee (Pepinsky, 2008). Such research could answer the question of how different formal institutions in autocratic system mediate these preferences in the formation of policy. It could also shed light on the types of selectorates likely to exist in different types of authoritarian regimes. A deeper examination of these questions can extend the knowlede of how autocratic institutios mediate social and elite preferences in the development of policy in a wide variety areas (Hankla, Kuthy, 2013, p. 503).

\section{Protectionism pressures in different political system}

It is important to indicate, that the role of trade unions in different political systems may be, to a high degree, different. In authoritarian systems it is, as a rule, smaller than in democratic systems. It would seem that if protectionistic pressure on the part of trade unions is weaker, the situation for economic growth is much better. Following that line of reasoning we could come to conclusion that the authoritarian system is better for the effectiveness of the labour market. The examples of Chile, South Korea, Singapore and Turkey from the seventies and early eighties could confirm that point of view. In many cases during those two decades the authoritarian regimes persecuted trade unions and put restrictions on basic labour rights. During that period of oppression, South Korea, Singapore and Turkey experienced a spectacular growth in the sector of processing industry and in the growth of demand for labour. Growing profits and the demand for labour in a processing industry, caused a general growth of prosperity of the employed. Although similar results were not noted immediately during the authoritarian phase of development in Chile, a number of observers express the opinion that the reforms introduced at that time helped to reorganise Chilean economy in the nineties. The application of democratic rules, on the other hand, may lead to lower productivity of labour force. In a number of years different democracies had to use significant financial resources for the employment of those who belonged to trade unions like for examle in the European Union.

A different point of view says that government legislation concerning the labour market may be applied more effectively in an authoritarian system than in a democratic one. The authoritarian regimes often make use of individual interests of given 
circles. In most democratic countries there is no broad enough basis that would allow to use labour market policy for gaining the support from pressure groups, the urbanised labour marked elite included. The major difference between authoritarian and democratic regimes lies in the level of the outside influence. In a well functioning democracy, the outside opinions are also taken into account and there occur some limitations which come from the outside, which restricts the achievements of given groups of interest. In a dictatorship, a government cares only that those groups are not too strong.

There is, however, a number of democracies among the industrialised countries where an effective labour market exists. There is also a number of democracies with effective labour market policy among the developing countries. Similarly, in the countries in which the transformation from the authoritarian regime towards a democracy is taking place, avoiding unfavourable phenomena on a labour market is often a priority. For example, the Chilean government moved towards democracy and to free trade unions without home income growth. The end of oppression in South Korea, in 1987, started the partnership relations in full of conflicts industry (Banerji, Ghanem, 1997).

It is worth considering which of the two points of view presented above should be given support, that is, which of them is the proper one. The analysis of that problem may be based on the Grossman and Helpman model (Grossman, Helpman, 1994). This model describes economic development on the basis of two sectors - urbanised, regulated processing sector, and rural, unregulated agricultural sector. The protection of the labour market, especially of minimum wages, is usually applied in order to bring the benefits for the employees of the regulated sector, since the sector of unregulated employees does not come under the legislation concerning the labour market.

The sector of regulated employees, and also the owners, demand from the government that it leads an economic policy that is favourable to them. The employed demand high minimum wages, while capitalists demand high profits. Both groups demand the restrictions on the degree of economy openness. In a closed economy, higher market minimum wages and higher profits are usually connected with higher prices for home consumers, and this is not easy when those consumers are free to buy the substitutes in form of imported goods. Thus, incomes in an economy may be created by protection and later divided among the employees of the regulated sector and the capitalists, although sometimes the government itself takes a part of those incomes (Banerji, Ghanem, 1997).

A government conducting an economic policy takes into account a number of factors. Firstly, it has to decide the degree of obtaining the resources, that is, how much from those resources it wants to obtain. Hence the importance of investments and of future economic growth, and also of defining the possibilities for keeping the power it is currently holding. Secondly, the government should define the scale of support from each of the pressure groups that can influence the situation. The position and importance of each group for the development of political processes should be considered. For example, in the country where the regulated labour market is divided, and politically weak, only the capitalists may have a deciding voice in political processes. And the contrary also happens - in the societies where the labour market is organised, it may play the important role in mobilising voters. 


\section{The level of protectionictic pressures}

The above arguments show that the policy is defined by political factors (including the type of the government and the burdens resulting from obligations towards employees and capitalists), and by economical factors (wages, prices, the structure of production and consumption). On the basis of the present discussion, we can present two equations, one pertaining to the level of protection, and the second pertaining to the national economy and deformation of wages.
1) $\pi=f(e, 1, k, R)$
2) $\varphi=f_{1}(\pi, e, 1, k, R)$,

The level of protection $(\pi)$ depends on the economic parameters (e), a relative political importance of urbanised employees and capitalists ( 1 and $\mathrm{k}$, respectively), and on the type of the government (R). Deformation of wages is, on the other hand, the function of $\pi$ and of $\mathrm{e}, 1, \mathrm{k}$ and $\mathrm{R}$. In case of a small economy, economic parameters that can influence $\pi$ and $\varphi$ include flexible consumer and producer prices, demand flexibility, wages and the demand for labour force, and also the price of goods on an international market.

One can expect, a priori, that the growth of $\pi$ is dependant on 1 and $\mathrm{k}$. If interest groups become stronger, the pressure to form incomes based on protectionism may become stronger. The influence of $\mathrm{R}$, that is, the influence of a political authoritarianism on the level of protectionism, that is, $\pi$, depends on the fact whether the opinion, that the level of protectionism depends on the effects of democratisation, is correct. It is also thought that the increase of the deformation of wages depends on $\pi$ and 1 , while its decrease depends on $\mathrm{k}$. As long as the incomes are obtained from trade protections, those incomes can be handed over to urbanised employees. An important problem in case of urbanised labour force as an interest group with growing strength is the fact that urbanised employees may gain a big share in the division of incomes but the growth of political importance of the capitalists may cause that the shared incomes, handed over to the labour force in regulated sectors of economy will become smaller (Banerji, Ghanem, 1997).

There is no doubt that it is easier for wealthy rather than poor societies to choose democracy (Helliwel, 1992). Since those wealthier societies at the same time have a tendency to a bigger openness, the direction of cause-result events may run from the openness of society to the political system, and not, as was suggested earlier, in the opposite direction. The research showed also that the level of education plays an important role in this respect. The countries with a higher level of education of labour force are more open.

On the basis of the earlier considerations, one can come to the conclusion that authoritarian systems have a tendency towards a broader application of protectionism than democratic systems, and that, in turn, the trade restrictions accompany significant deformations of wages on the labour market. This opinion may be justified on the basis of the observations of the situation in a number of countries.

Freedom of association is one of the elements of good management and the necessary condition for development. The authoritarian governments do not respect, however, 
the freedom of association, which is connected with the policy of trade restrictions and with the deformations on the labour markets. One cannot state, however, that improper or ineffective policy on the labour market belonged exclusively to authoritarian regimes or that authoritarianism automatically generates this kind of policy. There is a number of examples of authoritarian countries which do not conduct policies of that kind. The works of such authors as Fields or Freeman show that the repressions against the labour force are not necessary, if one wants to achieve a required economic growth (Fields, 1994; see also Freeman, 1993).

Finally, it should be pointed out that there exists a close relation between democracy and an economic growth, There are well known examples of open societies that stimulate the economic growth. This is true mainly in case of highly developed and strongly urbanised countries. In the countries with a developed democracy, the pressure groups have a bigger opportunity for acting. The research shows that the presence of trade unions helps to accelerate the economic reforms (Devarajan, Ghanem, Thierfelder, 1997). The benefits resulting from liberalisation of the international trade are bigger when the trade unions exist in the sector of the economy under protection. The growth of import abilities leads to the decrease of wage pressures, and when the trade unions agree to that, such a situation allows for a better allocation of labour force in the economy. This is true both in the case of active and passive trade unions, although the effects are better in case of active trade unions.

The trade unions active on an urbanised labour market had a significant influence on the decisions of governments, in the course of multilateral trade negotiations within WTO. It was especially evident in the negotiations on lowering customs duties and non-tariff measures in steel, shipbuilding, textile and clothing industries, and in coal mining. In the so-called "sensitive" industries, which, for example, in the European Union were under special trade protection, the position of trade unions was very strong.

\section{6 . The variation in the foreign trade policy among states}

It is important to underline that despite the pressure of international organizationss like WTO, there is a large amount of variation in trade policy among states (Kennedy, 2007, p. 145). In the modern activity of World Trade Organisation (WTO) very important are new forme of trade like in services, intellectual property rights and the trade related aspects of the investment policy. The WTO has a cursory agreement on trade-related investment measures (TRIMs). Talks over the Multilateral Agreement on Investment (MAI) broke down under OECD in 1998 because of the pressure from environmental and labor groups concerned with race to the bottom scenarios and also due to France's refusal to join the talks. In 1996, investment was one of four so-called Singapore Issues. But it was thwarted in Cancun in 2003 by developing countries for fear of domination by Western multinationals, and also by NGOs and civil society groups concerned about the adverse impact in environment and labor. The investment issue was thus dropped from Doha agenda (Pekkanen, Solis, Katada, 2007, p. 960). 
The WTO - through its agreements on safeguards and antidumping, offer some recourse for states to rein in the forces of free trade. However, many experts suggest that there are legal ambiguities in WTO regime that have limited invocation of safeguard measures (Komuro, 2001, p. 851; Kawase, 2006). Japan is moving toward the use of WTO-consistent safeguards. These concerns have been fueled because there is increasing Chinese competition in week industries and because it is harder to request supplying countries to take grey measures such as VERA in agriculture and textiles than it was in the past (e.g., edible fats from New Zealand; textiles from Korea and China). But officials do not appear to have high hopes of using safeguards as a matter of routine under the WTO because the text and precedents regarding the Safeguard Agreement are murky enough to deter successful invocation and because, if it takes place, invocation is scrutinized heavily in the WTO dispute-settlement system (Kawase, 2005; Kawase, 2006).

Trade policy takes on additional importance in economic battle of the valiant liberal reformers, fighting against self-dealing rent seekers profiting from inconsistencies of the transition economy (Aslund, 2002, p. 19; Kitschelt, Mansfeldova, Markowski, Toka, 1999). Many of the clientelist policies that shelter rent seekers are impossible to maintain in the face of competition in the international economy. On the other hand, high tariff walls, export licensing, and artificial exchange rates provide numerous sources of rents for business people who are trying to promote their own loyalties.

World trade growth in 2013 and 2014 is likely to be slower than previously forecast. WTO economists predicted 2013 growth of $2.5 \%$ (down from the $3.3 \%$ forecast in April) and $4.5 \%$ in 2014 (down from 5.0\%), but they say conditions for improved trade are gradually falling into place (Chart 1 , Table 1).

\section{Chart 1. World merchandise trade volume by level of development, 2010Q1-2013Q4 ${ }^{\mathrm{a}}$ Seasonally adjusted indices, 2005Q1 $=100$}

Export

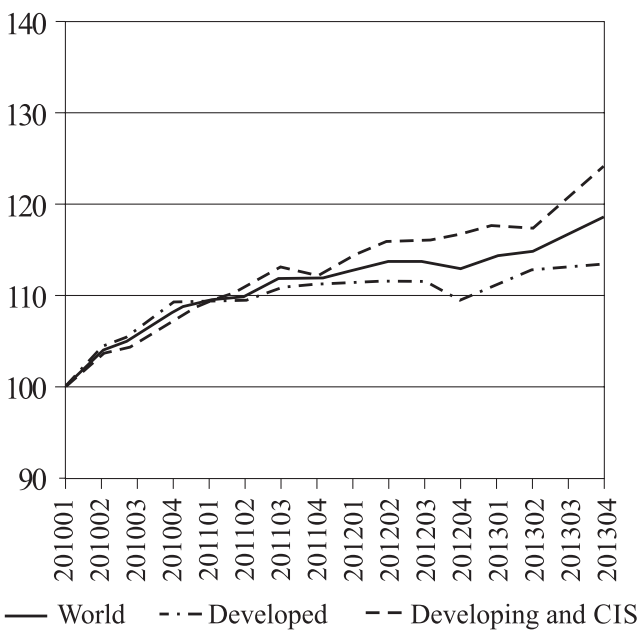

Imports

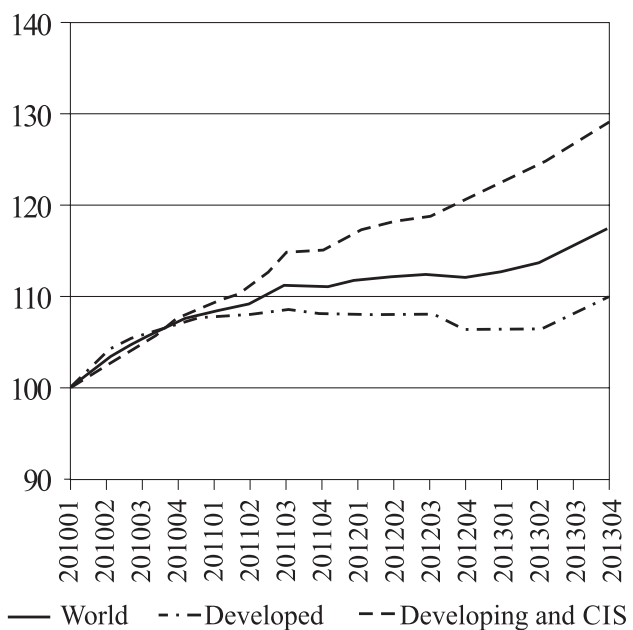

${ }^{\text {a }}$ Figures for 2013Q3 and 2013Q4 are projections.

Source: WTO Secretariat, http://www.wto.org/english/news_e/pres13_e/pr694_e.htm, 24.10.2013. 
World merchandise trade and GDP, 2009-2014

Table 1 Annual \% change

\begin{tabular}{|l|r|c|c|c|c|c|}
\hline & $\mathbf{2 0 0 9}$ & $\mathbf{2 0 1 0}$ & $\mathbf{2 0 1 1}$ & $\mathbf{2 0 1 2}$ & $\mathbf{2 0 1 3 P}$ & 2014P \\
\hline Volume of world merchandise trade $^{\mathrm{b}}$ & -12.5 & 13.8 & 5.4 & 2.3 & 2.5 & 4.5 \\
\hline \multicolumn{7}{|c|}{ Exports } \\
\hline Developed economies & -15.2 & 13.3 & 5.1 & 1.1 & 1.5 & 2.8 \\
\hline Developing economiees and CIS & -7.8 & 15.0 & 5.9 & 3.8 & 3.6 & 6.3 \\
\hline \multicolumn{7}{|c|}{ Imports } \\
\hline Developed economies & -14.3 & 10.7 & 3.2 & 0.0 & -0.1 & 3.2 \\
\hline Developing economiees and CIS & -10.6 & 18.2 & 8.1 & 4.9 & 5.8 & 6.2 \\
\hline Real GDP at market exchange rates & -2.4 & 3.8 & 2.4 & 2.0 & 2.0 & 2.6 \\
\hline Developed economies & -3.8 & 2.7 & 1.5 & 1.2 & 1.2 & 1.9 \\
\hline Developing economiees and CIS & 2.1 & 7.4 & 5.5 & 4.7 & 4.5 & 4.9 \\
\hline
\end{tabular}

${ }^{a}$ Figures for 2013 and 2014 are projections.

${ }^{\mathrm{b}}$ Average of exports and imports.

Source: WTO Secretariat for trade, Consensus estimates of economic forecasters for GDP, http://www.wto. org/english/news_e/pres13_e/pr694_e.htm, 24.10.2013.

The demand for imports in developing economies is reviving but at a slower rate than expected. This hindered the growth of exports from both developed and developing countries in the first half of 2013 and was the reason for the lower forecasts (Chart 1, Table 1). Although the trade slowdown was mostly caused by adverse macro-economic shocks, there are strong indications that protectionism has also played a part and is now taking new forms which are harder to detect. Negotiations under way in Geneva can address these problems, facilitating greater trade and opportunities to spur economic growth. Some short-term prospects are improving with encouraging data coming from Europe, the US, Japan and China. Reports on private sector activities from purchasing managers (purchasing managers' indices, which give some indication about future activity), shipping rates, automobile production and other leading indicators, suggest that the economic slowdown has bottomed out and that a tentative recovery is underway.

The European sovereign debt crisis has eased significantly since 2012 year, unemployment in the United States has fallen to $7.3 \%$ from a post-crisis high of $10 \%$, and growth of GDP (gross domestic product, a measure of a country's output) in Japan has accelerated since the adoption of new fiscal and monetary policies (Jackson, 2013). Although large developing economies have slowed appreciably, the latest figures from China on industrial production suggest that the country may be regaining some of its dynamism. On the other hand, India's economy is still in the midst of a sharp.

However, both extra-EU imports and trade between EU countries (i.e., intra-EU exports) have declined steadily since the middle of 2011, dropping around $2 \%$ year-on-year in the first half of 2013. Since the EU (including intra-EU trade) accounts for fully $33 \%$ of world imports and 58\% of developed economy imports, economic shocks there will be strongly reflected in world aggregates (Chart 2).

US exports and imports have been flat since the beginning of 2012, held down by weak external demand and slow growth at home. However, in the second quarter of the 2013 year, exports jumped $2.2 \%$ compared to the previous quarter $(9 \%$ when calculated 
PP 4 '21 Trade cooperation in light of the forces that are currently...

Chart 2. Merchandise exports and imports of selected economies, 2010Q1-2013Q2 Seasonally adjusted volume indices, $2010 Q 1=100$
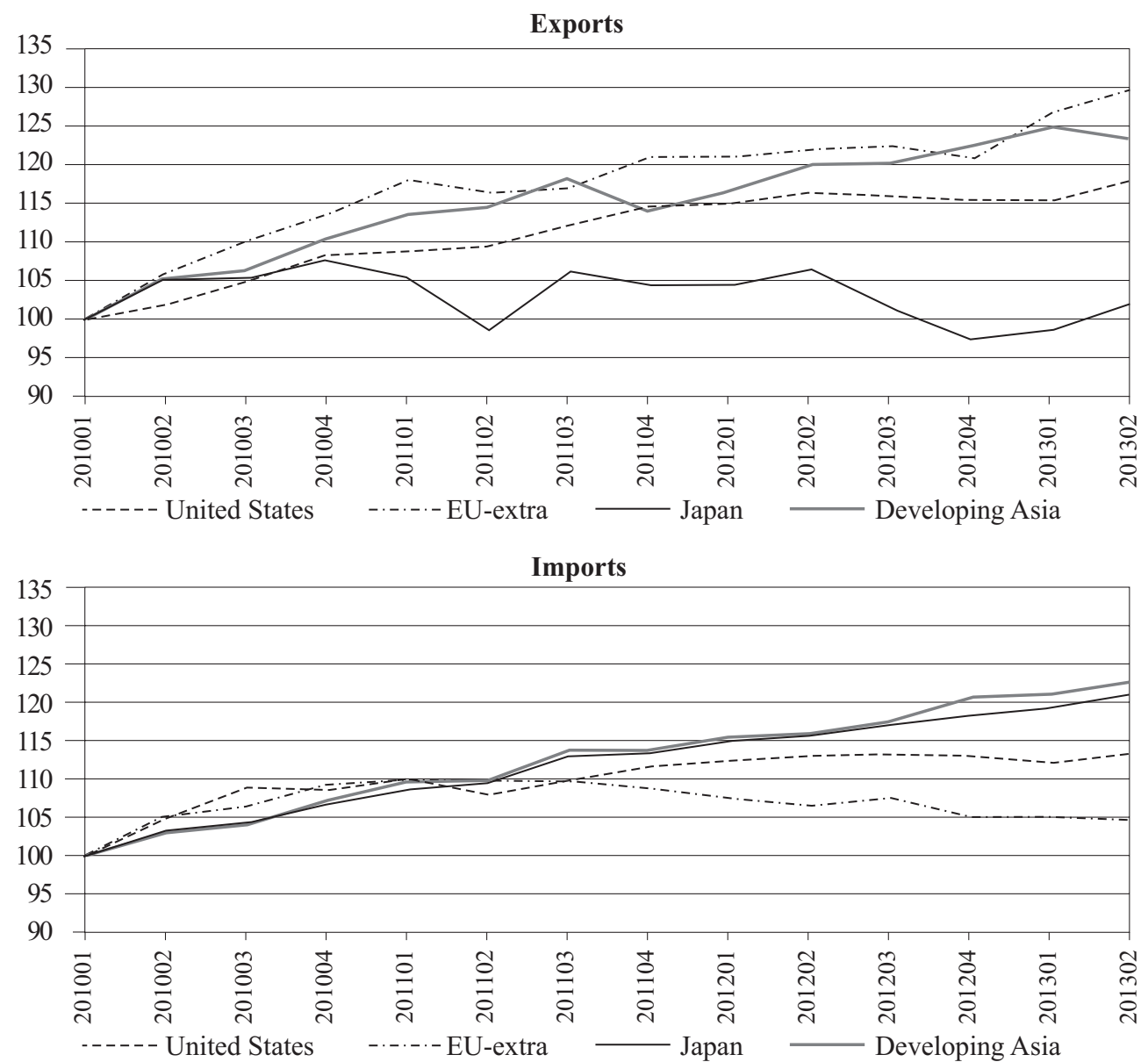

Intra-EU trade

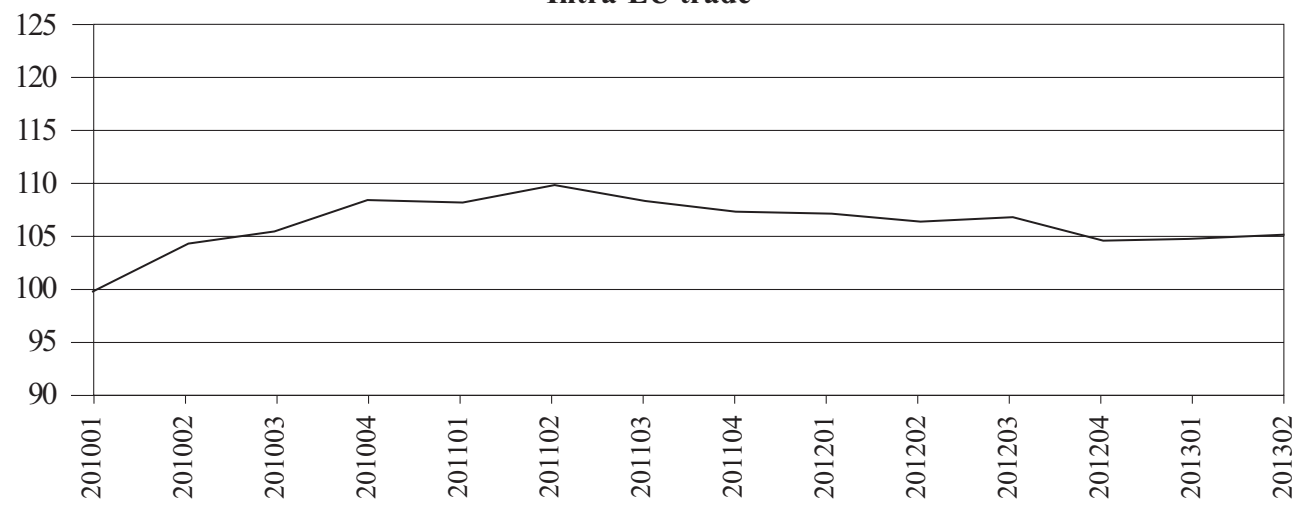

EU-intra (exports)

Source: WTO Secretariat, http://www.wto.org/english/news_e/pres13_e/pr694_e.htm, 24.10.2013. 
as an annual rate), while imports advanced $1.0 \%$ (4\% annualized), possibly indicating a turning point for US trade flows (Chart 2).

The other notably weak performance in Chart 2 is Japan's on the export side. The sharp dip in exports in 2011 is linked to the earthquake and tsunami that devastated Japan in that year. The more recent slump beginning in 2012Q3 appears to be related to a diplomatic dispute between Japan and China that has soured trade relations between the two countries. By the second quarter of 2013, Japanese exports were little changed since the beginning of 2010, but imports rose around 20\% over the same interval. Japan's export performance may be erratic, but since it only makes up $4 \%$ of world exports and $9 \%$ of developed economy exports it has less of a direct influence on broad aggregates (Chart 2).

Trade flows of developing Asia (which includes China) have maintained a steady pace of growth in recent years, but exports dipped 1.4\% in the second quarter of 2013 compared to the first quarter (5.4\% annualized) (Chart 2). This was due to a relatively sharp drop in China's exports, which could partly be related to weak demand in China's trading partners, but could also reflect recent Chinese efforts to correct for misreporting of trade values. However, since trade data are not revised for earlier years, it is unclear whether the drop in the second quarter represents and actual decline in trade flows.

\section{The liberalisation of China trade policy and their effects}

It must be emphasized that the access of China to WTO (November 2001) was the moment in which new trade rules became obligatory. In the next five years China eliminated all kinds of quotas and other non-tariff barriers that slow down the inflow of foreign goods. Customs duties which were lowered were gradually reduced to an average of $9 \%$. Foreign banks received the right to introduce the foreign ownership in $100 \%$ of economic fields and the right to take in the deposits from the Chinese in their own currency. The Chinese government no longer faces the serious problem of protecting domestic production from foreign competition with agricultural production as a possible exeption. In fact some other countries are facing cempetition from Chinese exports, to the point of threatening to use import quotas and higher tariffs on Chinese product (Chow, 2015, p. 322). It is important to underline four aspects of foreign trade and investment: the large amount of import from China, the outsourcing of job to China (and India), foreign investment to China, and technology transfer to China (Chow, 2015, p. 322).

China is now the biggest exporter and receiver of foreign investments (Chart 3), (Chart 4). China is the world's number one exporter after taking the top spot from Germany in 2009. China's total 2009 were US\$1.2 trillion, compared to Germany's US $\$ 1.17$ trillion (816 billion euros) (China's customs office, the Federation of German..., 2010). About 20\% of China's exports go to the United States (The World Bank, 2011). The U.S. is China's largest trading partner (LaFleur, 2010). In 2010, U.S. exports of goods to China jumped $32 \%$, to US $\$ 92$ billion. Seven of China's top 10 big partners in trade are in Asia continent (LaFleur 2010). Six of the world's largest container ports are in China (Trading Places, 2010). China was the second-largest recipient of Foreign Direct Investment (FDI) in 2009 (United Nations, 2010). China attracted \$105.7 billion in 
foreign direct investment in 2010 - the first time FDI in China crossed the $\$ 100$ billion mark (China FDI rises strongly..., 2011); (Foreign Direct Investment, 2011).

Chart 3. Stock of outward foreign direct investment (\% of world total)

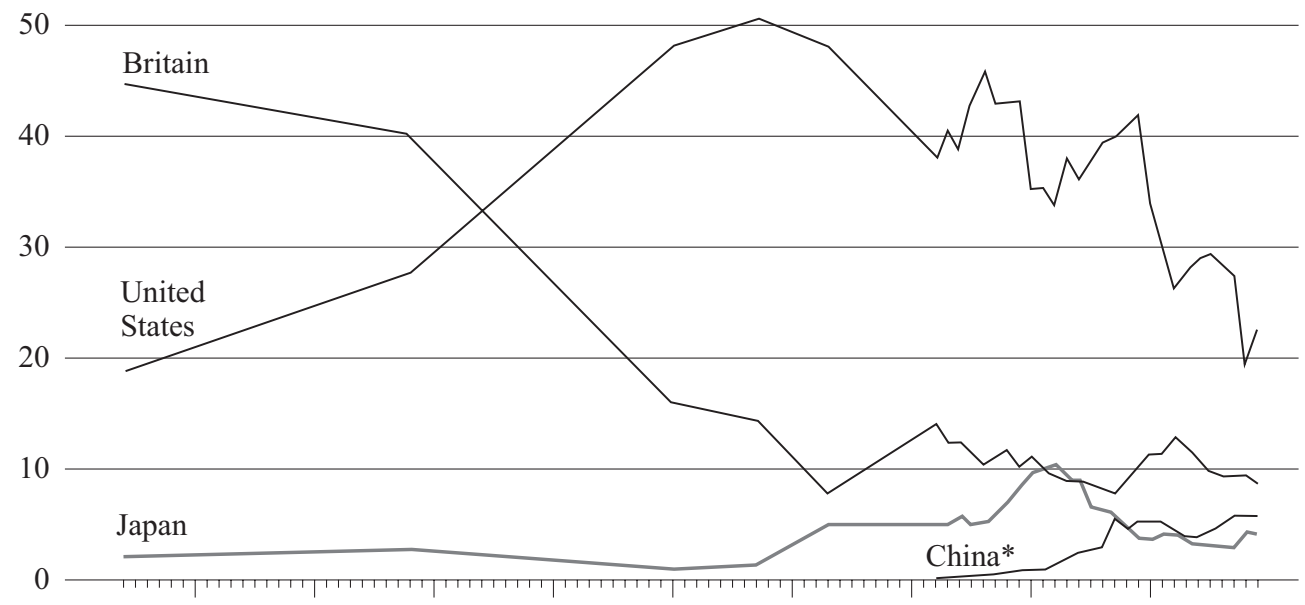

* Incuding Hong Kong and Macau.

Source: UNCTAD, 11.10.2013.

China's weak currency - which is good for Chinese exports - also makes the yuan (RMB) one of the most undervalued currencies. China is poised to make its money a global currency, which could strengthen China's influence in overseas financial markets and begin to erode the dollar's dominance. China's has over US\$1 trillion in foreign exchange reserves (exceeding Japan's), and continue to grow around \$200 billion each year (The World Bank, 2011). China owns over $25 \%$ of U.S. Treasury Bonds and is the largest creditor in the world (Rediff Business, 2010). China is also the U.S.A.'s largest creditor, holding more than $\$ 900$ billion worth of U.S. The second and threeted creditors are Japan and the U.K. (Factbox: China leads..., 2011).

China's emerging market stocks are predicted to quintuple in the next two decades-reaching a market value of around $\$ 80$ trillion by 2030 (Sachs, Moe 2010). The Shanghai Stock Exchange is the fifth largest stock market in the world (market capitalization of US \$2.7 trillion) (List of stock..., 2013). Eight of the ten largest stocks on the Shanghai Stock Exchange are state-controlled enterprises (Shanghai Stock Exchange, 2013), 98\% of China's banking assets are state-owned, as are most of China's financial institutions (Rediff Business, 2010). China's state-controlled entities are not particularly profitable. The average return on equity for companies wholly or partly owned by the state is barely $4 \%$. In comparison, the returns of unlisted private firms are no less than ten percentage points higher. In China a new economic era has recently begun, described as guo jin min tui: state advances, private retreats (Let a million, 2011). The number of registered private businesses in China grew by more than 30\% a year between 2000 and 2009, but these figures exclude unregistered businesses. No one knows quite how much private companies contribute to China's fast-growing economy. However, enterprises that are not majority-owned by the state account for two-thirds of industrial output (Let a million, 2011) (Chart 5). 


\section{Chart 4. Foreign direct investment (FDI inflows, 2010 estimate, $\$$ bn)}

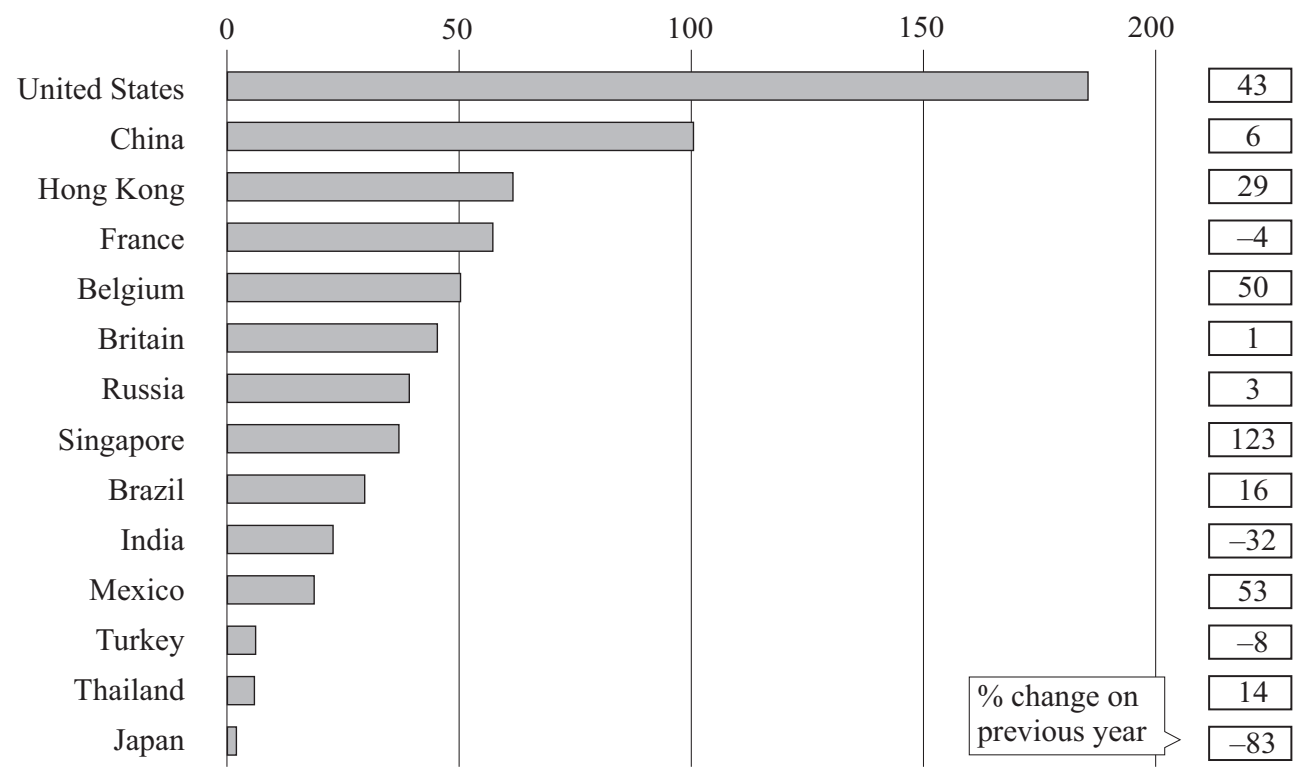

Source: UNCTAD, 11.10. 2013.

Chart 5. Firm advance. China industrial enterprises

500

Total

L of which: private

400

300

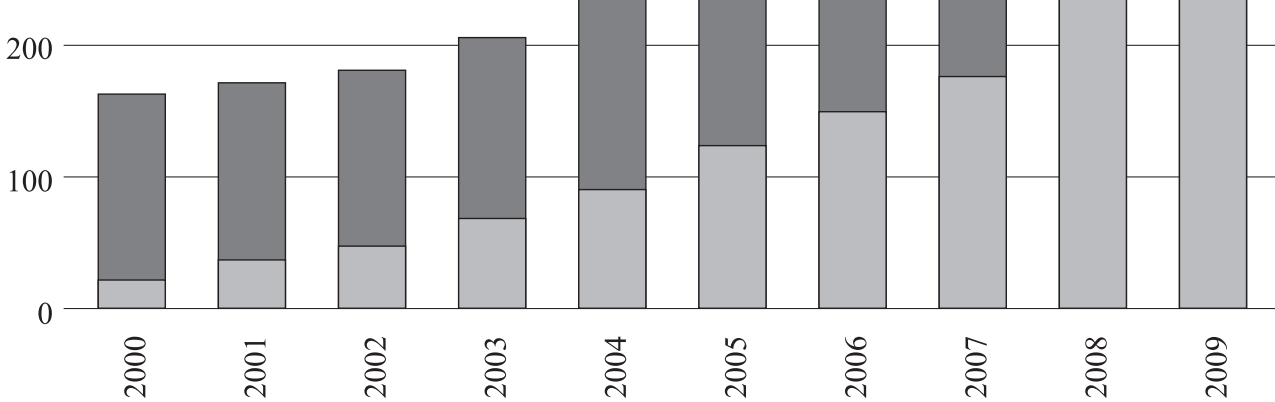

Source: China Macro Finance. Revenues over 5 m yuan (RMB), http://www.china-mike.com/facts-aboutchina/economy-investment-business-statistics/, 11.10.2013.

China's private firms account for about $75-80 \%$ of profit in Chinese industry and 90\% in non-financial services (Let a million..., 2011) (Chart 6). 
Chart 6. The receding state. China state-owned enterprises' share of industrial (\%)

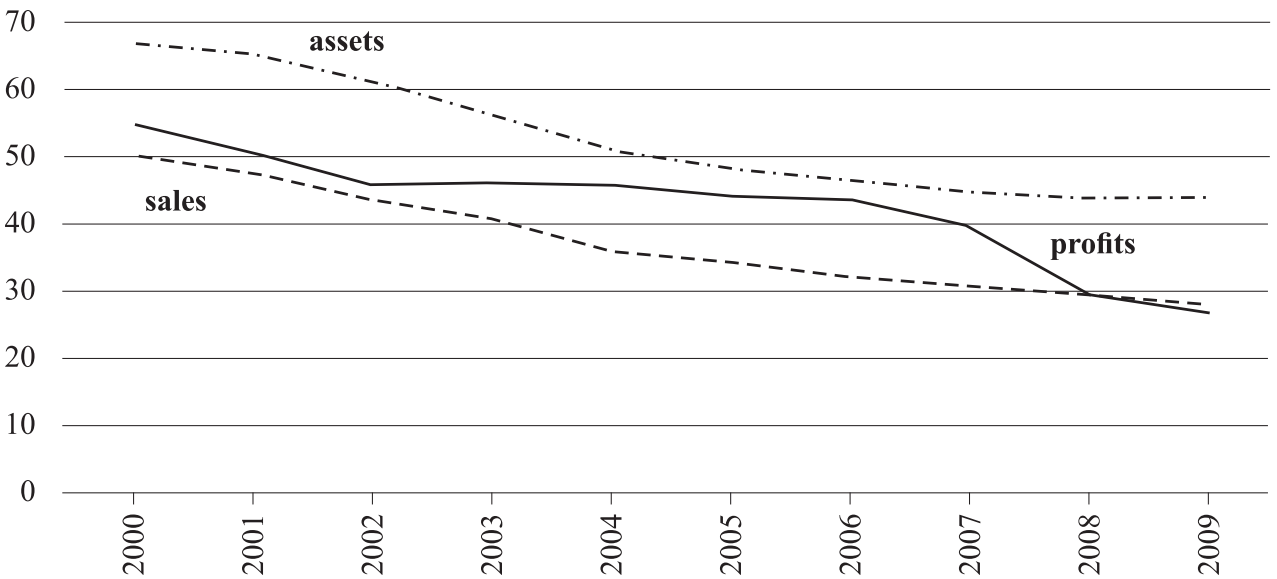

Source: CEIC: Keywise Capital Management, http://www.china-mike.com/facts-about-china/economy-investment-business-statistics/, 11.10.2013.

Chart 7. GDP per capita of China in comparison with the most developed countries (in trillions US\$)

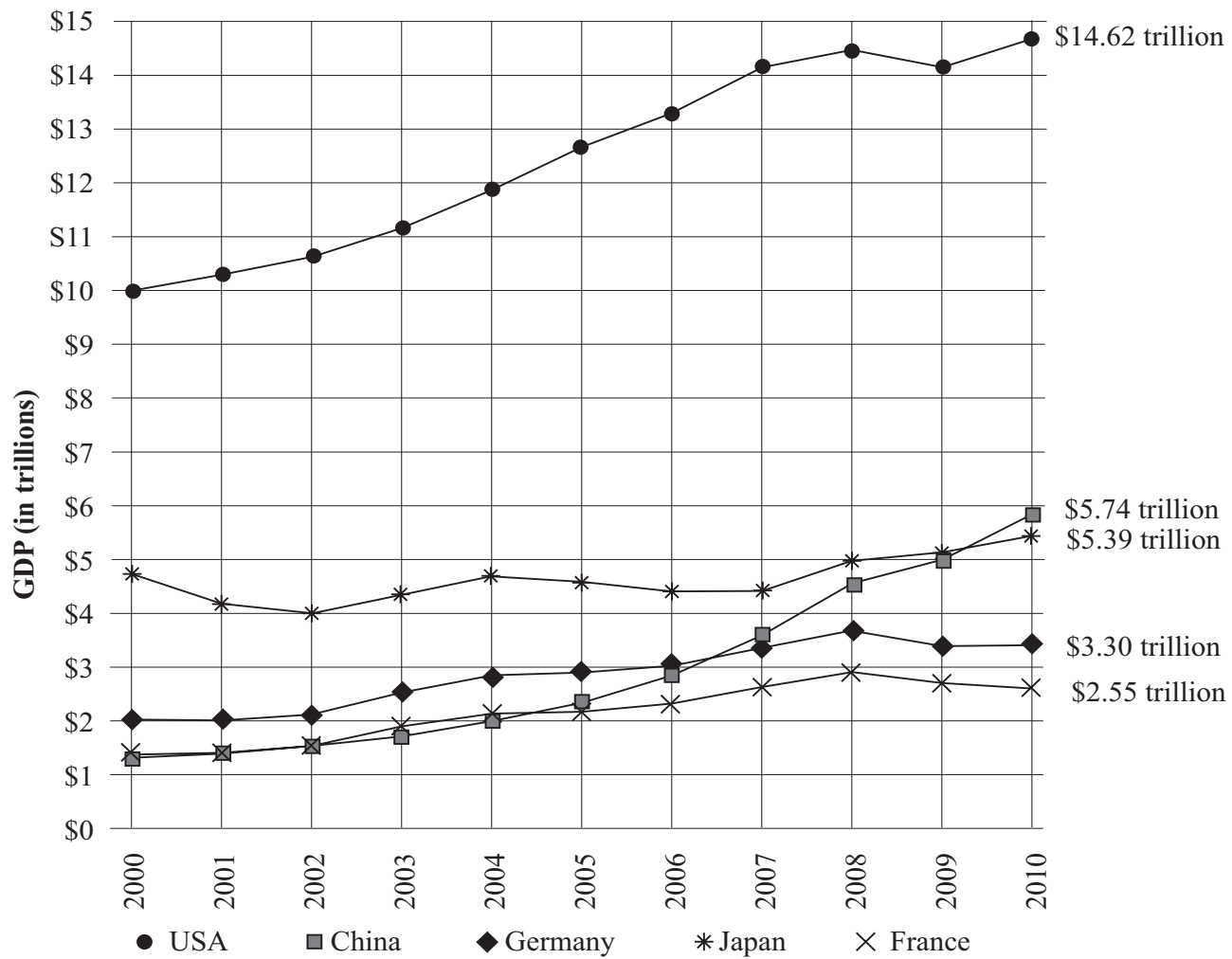

Source: World Bank: CIA Factbook (2010), http://www.china-mike.com/facts-about-china/economy-investment-business-statistics/, 11.10.2013. 
China in the half of second decade of XXI century was the world's fastest-growing major economy, with an average growth rate of $10 \%$ for the past three decades years. In 2000, China's accounted for only 7.1\% of the world's total GDP (in PPP terms). In 2010, that figure increased to $13.3 \%$. By 2020, it is expected to reach $20.7 \%$ (Top 10 largest economies in 2020, 2010). In 2000, China topped Italy to become the world's sixth-biggest economy. In 2005, China overtook France to become the fifth-largest. In 2006, it moved up again by knocking off the U.K. In 2007, China became the third-largest economy by topping Germany (China is richer..., 2011) (Chart 7, Chart 8).

Chart 8. GDP growth: per capita (in thousands)

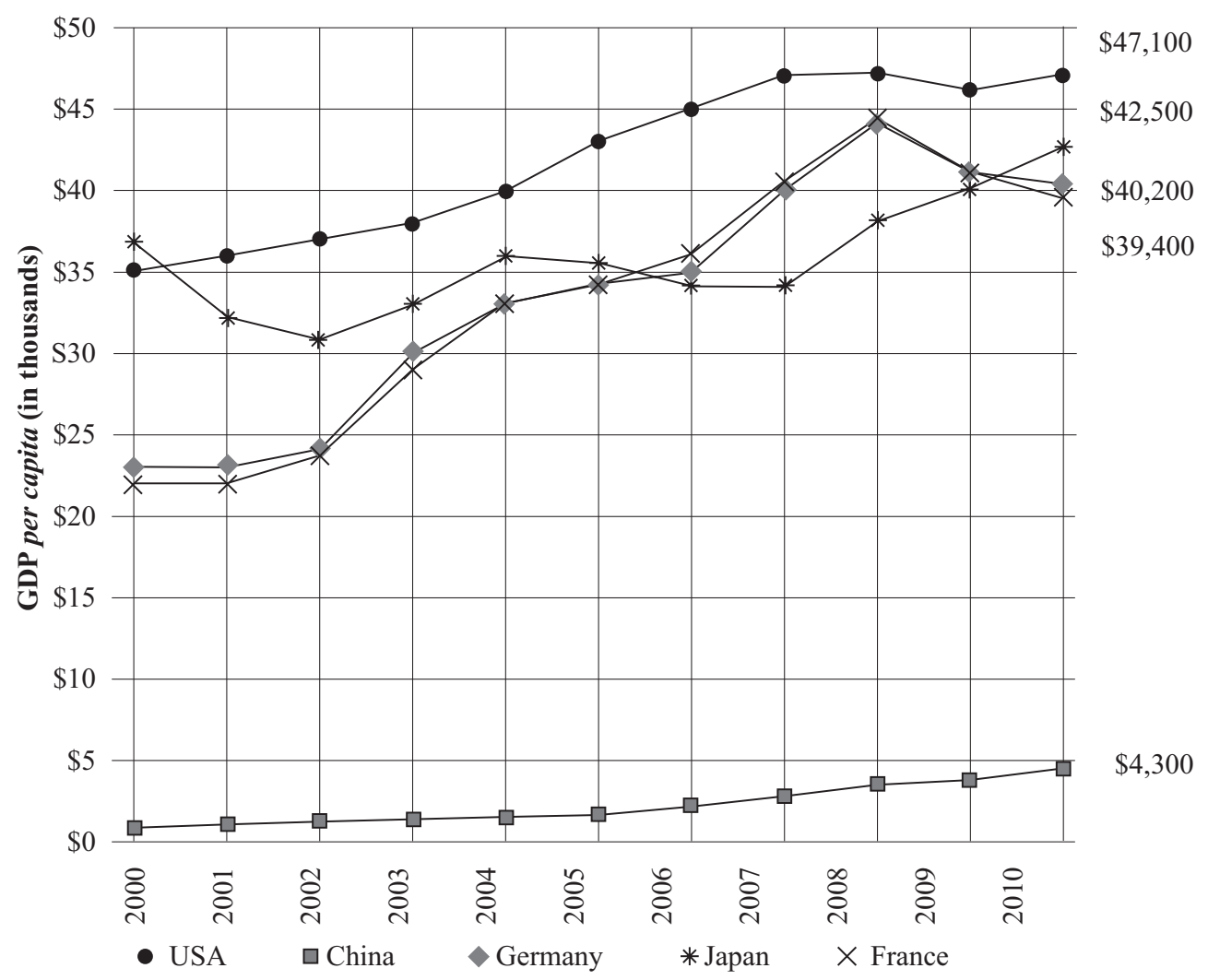

Source: World Bank: CIA Factbook (2010), http://www.china-mike.com/facts-about-china/economy-investment-business-statistics/, 11.10.2013.

However, China's per capita GDP still only ranks \#127 (2010), just under that of Albania and Turkmenstan (CIA World Fact Book, accessed 2011).

China is the world's second largest economy, after overtaking Japan in 2010 (Chart 7, Chart 8), Chart 9) (“The Economist", 2010). It is important to underline that China could overtake the U.S. as the world's biggest economy by 2030, according to economic experts (China Passes Japan..., 2010). 


\section{Chart 9. Shifting Fortunes (\$ trillion)}

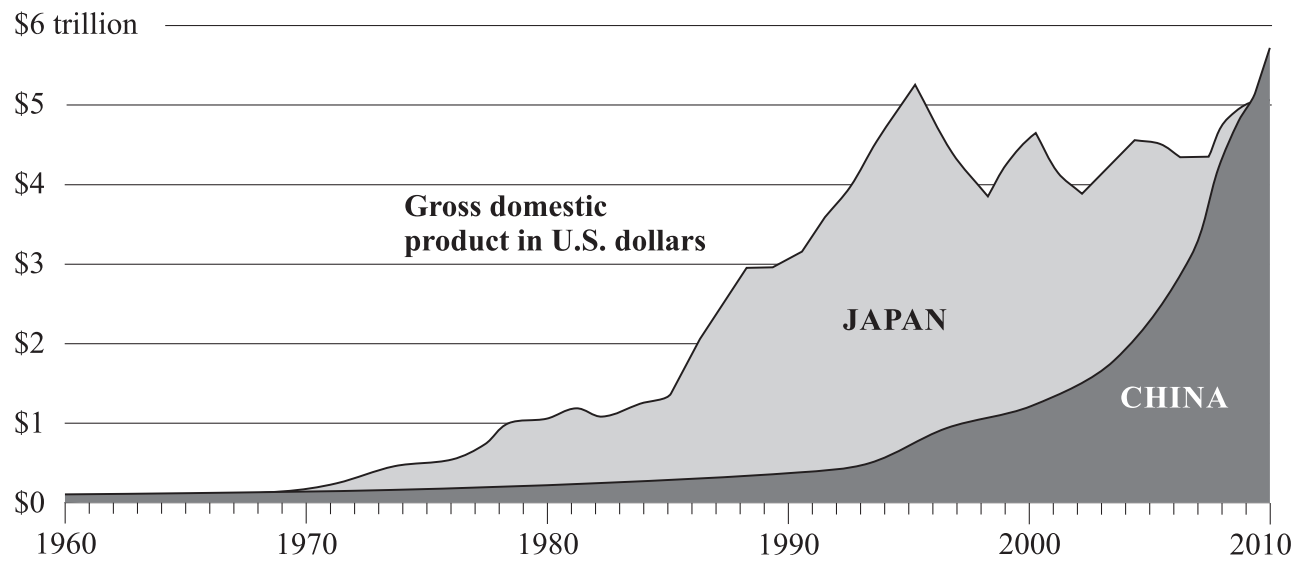

Source: World Bank; International Monetary Fund, http:/www.china-mike.com/facts-about-china/economy-investment-business-statistics/, 11.10.2013.

According to Goldman Sachs Group Inc. chief economist Jim O’Neill, China could overtake the U.S. as the largest economy as early as 2027. China's economy could overtake the U.S. economy by 2019, "given reasonable assumptions," according to "The Economist" in 2011 (Chart 10). It must be underline that China's population is enormous. It has over four times as many people as America, and so its output per capita only needs to be about a fourth of America's to match it in total size" (How to gracefully step..., 2011).

Chart 10. Passing the back. GDP*, \$trn.

Based on the long-term assumptions, annual average, $\%$

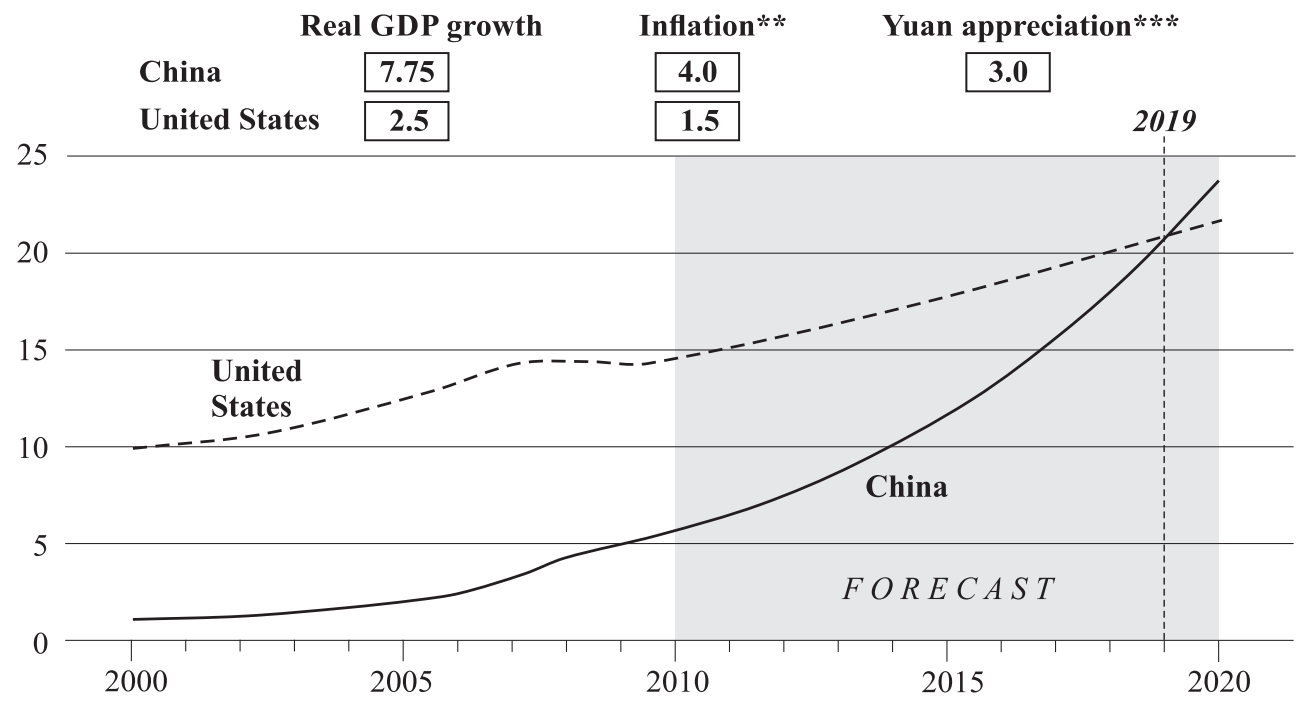

* At current prices and market exchange rates; ** GDP deflator; *** Against the dollar.

Souce: The Economist, http://www.china-mike.com/facts-about-china/economy-investment-business-statistics/, 11.10.2013. 
Estimates by R. J. Tammen at al.(2000) anticipate that China will overtake the United States in mid-century (Tammen, Kugler, Lemke, Stam, Abdollahian, Al-Sharabati, Efird, Organski, 2000). Thus American dominance should endure until mid-century. Afterwards, Asian demands for modification to the international system will likely increase, and unless resolved, will be increasingly likely to be imposed by force (Table 2), (Mape 1). The question raised by this empirically grounded extrapolation is whether the West will see China's rise as an opportunity for cooperation (as former European enemies did when responding to the post-World War II resurgence of Germany by creating the EU) or for conflict (Kugler, 2006, p. 39).

Table 2

The global balance of economic powers in 2010 versus 2020

\begin{tabular}{|l|l|c|l|c||}
\hline \hline Rank & \multicolumn{1}{|c|}{ Country - 2010 } & GDP (US million) & \multicolumn{1}{c||}{ Country - 2020 } & GDP (US million) \\
\hline 1 & USA & $14,802,081$ & China & $28,124,970$ \\
\hline 2 & China & $9,711,244$ & USA & $22,644,910$ \\
\hline 3 & Japan & $4,262,492$ & India & $10,225,943$ \\
\hline 4 & India & $3,912,911$ & Japan & $6,196,979$ \\
\hline 5 & Germany & $2,861,117$ & Russia & $4,326,987$ \\
\hline 6 & Russia & $2,221,755$ & Germany & $5,981,033$ \\
\hline 7 & United Kingdom & $2,183,277$ & Brazil & $3,868,813$ \\
\hline 8 & France & $2,154,399$ & United Kingdom & $3,360,442$ \\
\hline 9 & Brazil & $2,138,888$ & France & $3,214,722$ \\
\hline 10 & Italy & $1,767,120$ & Mexico & $2,838,722$ \\
\hline \hline
\end{tabular}

Source: Facts about China: ECONOMY \& GDP 2011-2012, http://www.china-mike.com/facts-about-china/ economy-investment-business-statistics/.

It is important underline that intensive development through economic growth is generally preferable to military and extensive expansion. With new investments, a country can transform its position through industrial expansion at home and sustain it through international trade. Access to the economies of other nations is sufficient; a rising nation does not need territorial control of them. Peaceful development can thus take the place of aggressive expansion. Since World War II, a number of economies have adopted this principle, including Germany, Japan, China and other East Asian Nations (Rosecrance, 2006, p. 33).

China will enter a world market in which many of the spoils have already been appriopriated. But fewer and fewer major firms may actually dominate the world economy. Some countries, like Mexico, will posses few, if any, decreasing cost industries. They will have to send their labor elsewhere to retain economic advantage. China will be studded with United States, Japanese, and European firms contributing high technology to Chinese development. Aside from textiles, however, it is not clear how many purely Chinese industries will attain economies of scale.

Under these circumstances, even very strong countries economically will be at least partly dependent on industries headquartered somewhere else. Even today, America does not represent the attainment of unipolarity in economics, whatever its military might. It is dependent upon money market and foreign direct investment from China, Japan, and Europe. Economic concentration today has three or four different nodes, not just 
Mape 1. Countries and Consumers. Top biggest economies: 2010 vs 2020
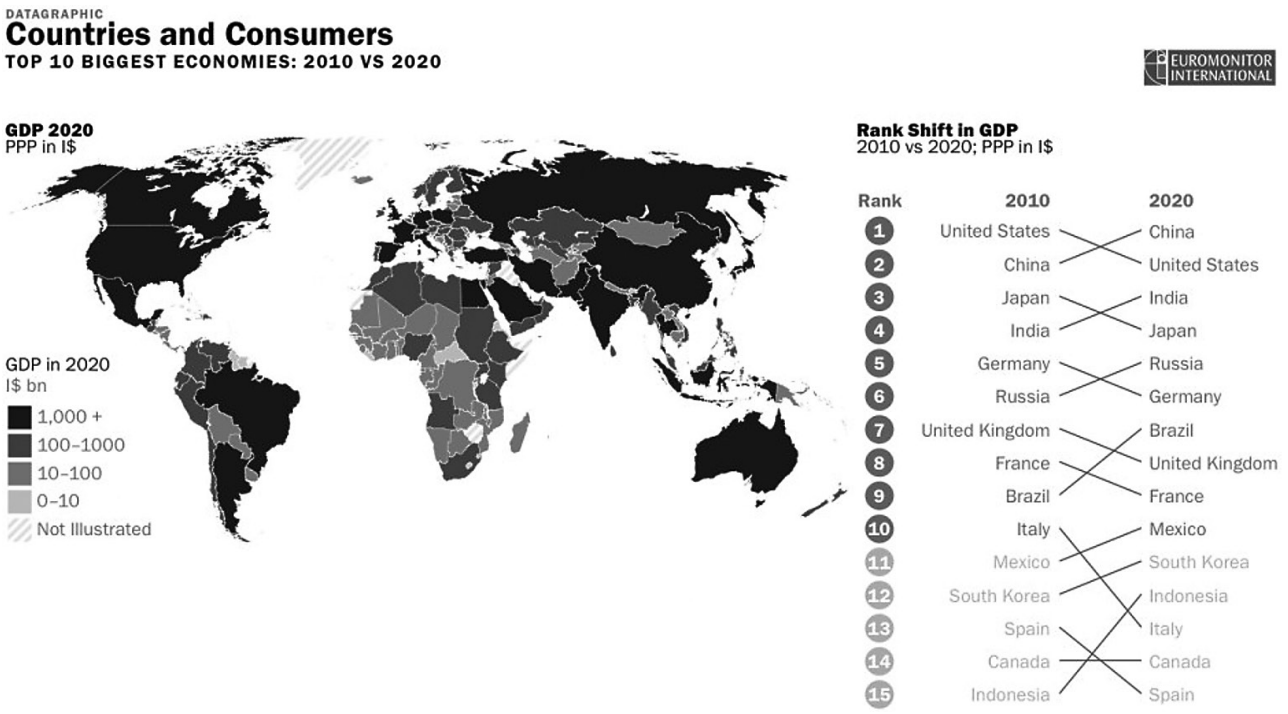

Source: Facts about China: Economy \& GDP 2011-2012, http://www.china-mike.com/facts-about-china/ economy-investment-business-statistics/.

one. The same will be true in 2020 or 2030. Decreasing cost (increasing returns) industries will be located in different zones and no one Great Power will monopolize them all. Europe will boast the London-Frankfurt and Zurich-Milan corridors. America will find large-scale competitive champions in two zones-Boston to North Carolina and San Diego to Seattle. China will have industrial or software concentrations in north China, Fujian, and Guangdong terminating in the Pearl River Delta. But no country, however powerful in terms of GDP, will incorporate all worldwide industrial or service potential. It is even possible that the defense industry on an international basis is one of increasing returns to scale. Under the circumstances, there will be overlapping zones of economic competency among Great Powers, and some countries will be left out altogether.

The assumed result of one Great Power hegemony replacing another and a shift between unipolarities will not be obtained in the next few decades. Thus, even very powerful countries militarily will find themselves needing the products and markets of countries (and corporations) located somewhere else. In theory, a very strong power militarily might be able to expand to take over the industries on which it has become dependent, but for a host of reasons this is unlikely. Again, cost-benefit reasons would cut against any attempt at conquest - opennes would provide acces to such industries much more efficiently than seizure that would not be successful in the longer term (Rosecrance, 2006, p. 35).

One, of course, cannot be sure that the more full-throated globalization of the present and future will remedy the difficulty. History shows that states sometimes engage in war for insufficient reasons, neglecting the ties that bind nations together. Short-term motives take procedence over long-term maximization. But they are not likely to do so between the United States and China, both long-term maximizers. China is especially sensitive 
to the advantages of intensive growth and will not wish to disrupt essential economic arrangements that have been crucial to her success.

In addition, should she decide otherwise, there are neighboring power that would present barriers to extensive expansion. Japan, a unfied Korea, India, and Russia all border on China. Even if the United States were not a major power guarantor of the existing settlement, these powers would make Chinese external expansion difficult if not imposible. Japan, perhaps, has traditionally underused her power, but this is not true of Russia or India. A unified Korea will represent another uncertainty for China. Again, economic ties with these nations will be preferable to military expansion against them. And the presence of the United States and its military bases will occasion additional hesitation. No one can be certain that relations among Great Powers will be peaceful ones over the long term. But the current economic, political, and military relationships make that prospect much more likely than it has been in the past (Rosecrance, 2006, p. 35).

8. The tendencies to liberalisation of foreign trade policy and natural environment protection

The tendencies to liberalise the international trade often stand in clear conflict with the protection of the natural environment. The pressure groups acting for natural environment protection see the trade policy in two aspects: as the way of improvement the standards of environmental protection in individual countries and over their borders, and as the instrument for persuading those countries to sign the international agreements on environmental protection.

In trade policy, of discriminating means in relation to the environment, is in accordance with the article XX of WTO, and it testifies to the fact that trade barriers are used for the protection of the environment. In this context it is important to underline that, the activities related to environmental protection are in conflict with the tendencies leading to international trade liberalisation. From the theoretical point of view, we cannot say that trade liberalisation may help the environmental protection (Chichilnisky, 1994, pp. 851-874; see also Copland, Taylor, 1995, pp. 716-737; Corden, 1996). When some government find itself in a difficult situation, the trade reforms will be much more preferable for that government than the actions in the environmental protection area (Bhagwati, Srinivisan, 1996). In this situation the pressure groups connected with the environmental protection are against the international trade liberalisation. An agreement between the problems of international trade liberalisation and the protection of natural environment especially in the context of the sustainable development also is an important task for the WTO. In the context of the sustainable development, the main problem is to make a proper choice: is the introduction of restrictions on international trade the more effective, or will the profits from environmental protection (as applied by a multilateral trade system) be higher than the costs?

Reaching the agreements on the international trade liberalisation and on very important in China environmental protection in the light of sustaiable development is considered to be both very difficult and very delicate question. The problems of environmental protection in China because of the very intensive industry production have become most 
important issues. The control of pollution resulting from production using existing technology in China is difficult one way for environment protection is to promote the use of clean energy by reducing its price relative to the price of existing energy. This can be achieved by imposing a cost to using pollution energy (which is hard to enforce) or by promoting technological innovations for the development of clean energy, especially to replace the use of coal. There are incentives in the free market for such innovations to take place. In addition the government can promote such innovations by subsidy and tax policies if it can identify them correctly (Chow, 2015, p. 187).

There are the appeals to multinationals doing business in China to play a positive role in protecting China's environment by setting an exemple for practicing environmentally friendly production while impressing the Chinese government of such conduct in their pusuit of profits. If it is in the self-interest of the multinationals to do so, one wonders why this would not also be to the self-interest of domestic Chines firms. If such an understanding is to their self-interest why have the multinational and Chinese domestic enterprises failed to do so? An economist would question that the multinationals and Chinese enterprises are ignorant of their self-interests in this regard (Chow, 2015, p. 187). It is also evident that the international market has to take the problems of environmental protection in China into account.

It is necessary also to emphasis that if the rules of international trade are clear - and if they are perceived to be supportive of important environmental values - then their legitimacy will be much greater. Over the long term, public support for the WTO depends on a perception that it is balanced and fair (Esty, 1998, p. 123). Efforts to adress the issues identified above could greatly enhance the WTO's reputation. Competing trade and environmental principles could best be balanced through creation of an interpretive statement that focuses on how the "exeptions" spelled out in Article XX would be implemented, rather than through full-blown renegotiation of the environmental elements of the trading system (Esty, 2000, pp. 250-251).

Finding ways to adress the environmental issues that inescapably arise in the context of deeper international economic integration and tendency to the sustainable development must be seen as an important trade policy priority, as a matter of WTO commitment to undergirding the trade regime with sound economic theory, and as a matter of political necessity. Building a system of trade that is more sensitive to pollution control and natural resources management issues is mandated by the growing degree to which these realms intersect with trade and environmental policies mutually reinforcing are also advisable to the extent that the presence of trade rules that internalize externalities will prove to be more economically efficient over time. Institutionalizing the links from the trade regime to environmental actors and other elements of civil society will also pay dividends. A culture of opennes within the WTO is likely to generate policies that the public accepts and that therefore become more useful and durable (Esty, 2000, p. 250-251).

\section{The tendencies to bilateralism in the foreign trade policy}

The tendencies in foreign trade policy development can create changes in domestic markets, placing pressure on political actors to obtain aid from the government espe- 
cially during the economic crisis (Krist, 2013; Jackson, 2013; Ravenhill, 2014). There are also the groups which want to coordinate activities and change foreign trade policy. Government provide the justification for protection of the domestic market to response to global competition. Essentially, the government appears to supply protection for affected parties; yet, the overall impact on consumers, producers, and foreign competition is neglible (Thies, Porche, 2007). Significant government ownership of the productive resources of a country has a negative effect on trade liberalization, while fragmentation of decision-making authority, expressed as fragmentation within the government and pluralism in society, has a positive impact on the libaralization of trade policy (Kennedy, 2007; Krist, 2013).

In the area of foreign-policy analysis has focused on "three i's": interest groups, international structure, and ideas (Kennedy, 2007). In the interests groups literature, government policy is viewed as the outcome of competition between groups for trade policies that benefit their industry (Nau, 1989; Milner, 1995; Milner, Yoffie, 1989; Schattschneider, 1935). International structure suggests that freer trade was a reflection on U.S. interests and its hegemonic status after World War II (Krist, 2013; Kirshner, 2013), while a decline in free trade is a reflection of the U.S.'s hegemonic decline (Krasner, 1976; Krist 2013; Kirshner, 2013). The literature on ideas suggests that policy belifs are reflected in laws and institutions (Jones, 2015). These laws and institutions, in turn, carry a type of interia that continues to influence policy outcomes long after changes in international and domestic structure would predict policy change (Goldstein, 1989; Goldstein, 1995; Jones, 2015). The institutional problems suggests that the current WTO system cannot create the conditions to deliver consensus on multilateral trade liberalization (Jones, 2015). In contrast to these explanations government interests in the economy and in maintaining stability also play a large role in trade policy (Kennedy, 2007; Jackson 2013).

At one end, a multilateral forum with near universal membership offers maximization of gains from trade and reduced transaction costs. However, a single state cannot expect to have much control over trade partners or liberaliztion agendas at the multilateral level (Jackson, 2013). At the other end, a bilateral FTA (Krist, 2013; Jones, 2015) often yields very small gains from trade and usually increases transaction costs by producing idiosyncratic sets of rules. But at the same time, a large state can acquire a high level of control in terms of partners, issues and agenda selection, and sectoral exclusions or inclusions based on domestic political needs (Pekkanen, Solis, Katada, 2007). One can contend that industrialized of aggregate economic gains in the interest of national welfare (largest in multilateral forums) or seeking control over rules in line with political interests (greatest in bilateral forums) (Krist, 2013; Jones, 2015).

The liberalizing rules on agriculture, and other less competitive sectors, are no longer an acceptable political price for the economic gains bundled across sectors (Jackson, 2013). Such policies, they contended, allow farm products to be sold at artificially low prices, thus undermining the sales of products from poorer regions, Farmers in developed countries have had considerable success blocking trade reforms in agriculture before and the WTO has been less succesful lowering barriers in this field than in others (Jackson, 2013). Yet, this sort of vague statement fosters uncertainty for domestic actors at home in uncompetitive sectors like agriculture (Eagleton-Pierce, 2013) and in several 
cases like for exemple in Japan and China trade officials need to show that they have more concrete control for political reasons-an element more credible in a bilateral setting (Krist, 2013; Jones, 2015) than a multilateral one (Pekkanen, Solis, Katada, 2007; Jones, 2015). This situation may also indicat the back from globalisation to the neomercantilist tendencies in the foreign trade policy (Krist, 2013; Jackson, 2013).

It is important to underline that a few multinational firms are responsible for a major share of world trade. On the one hand, these firms should support regulatory harmonization across different PTAs in order to lower trade costs. On the other hand, they might also resist harmonization - and encourage certain non-tariff measures - in order to prevent new competitors from entering markets. This may partly explain the persistence of regulatory divergence, and suggests that the political economy of regulatory convergence may be more complex than is sometimes suggested.

\section{Results and Findings}

The trade liberalization has a special positive significance in the global context.. However the international trade policy is strongly affect by the force and trends of the world economy development. The changes are evident in the growing importance of international trade to national economies and to domestic groups within those economies, in the closer linkages between trade and other international issues. In this context it must be emphasis that on a theoretical level, understanding the choice of trade policies between liberalizm and protectionisme in countries is very important.

Question is how can we recognise the type of power, the type of rule? First of all, we should investigate what level of resources a given government is going to achieve. If an authoritarian government is more or less corrupted than a democratic one, it will be creating the income, to a bigger or lesser degree, through protectionism. It will also appropriate some part of that income. Secondly, a given type of government may remain under the influence of different pressure groups. If an authoritarian government is trying, to some extent, to subordinate special pressure groups including the regulated labour sector, it will be, to some extent, generating incomes through protection and it will be turning over some part of them to those special pressure groups.

It should be pointed out that there exists a close relation between democracy and an economic growth, There are well known examples of open societies that stimulate the economic growth. This is true mainly in case of highly developed and strongly urbanised countries. In the countries with a developed democracy, the pressure groups have a bigger opportunity for acting. The research shows that the presence of trade unions helps to accelerate the economic reforms. The benefits resulting from liberalisation of the international trade are bigger when the trade unions exist in the sector of the economy under protection. The growth of import abilities leads to the decrease of wage pressures, and when the trade unions agree to that, such a situation allows for a better allocation of labour force in the economy. This is true both in the case of active and passive trade unions, although the effects are better in case of active trade unions.

Trade policy takes on additional importance in economic battle of the valiant liberal reformers, fighting against self-dealing rent seekers profiting from inconsistencies of the 
transition economy. Many of the clientelist policies that shelter rent seekers are impossible to maintain in the face of competition in the international economy. On the other hand, high tariff walls, export licensing, and artificial exchange rates provide numerous sources of rents for business people who are trying to promote their own loyalties. The reduction or the elimination of trade restrictions stimulates significantly the growth of the world trade exchange, while the foreign trade, in turn, is an important factor of the economic growth of individual countries.

Scholary unterstanding of the behavior of authoritarian regimes will need to be tied closely to an examination ot their institution and institutionalization. Perhaps the most fruitful arena for future research will be to focus on the specific preferences of selectorates composition and policy outcomee. Such research could answer the question of how different formal institutions in autocratic system mediate these preferences in the formation of policy. It could also shed light on the types of selectorates likely to exist in different types of authoritarian regimes. A deeper examination of these questions can extend the knowledge of how autocratic institutios mediate social and elite preferences in the development of policy in a wide variety areas.

Further trade liberalisation and improved framework policies would increase trade and promote growth. It must be emphasized that openess to trade is associated with higher incomes and growth and there are the need for new approaches to trade cooperation in light of the forces that are currently re-shaping international business. A major factor, was the even more remarkable transformation of China, as market reforms opened up its economy to foreign trade and investment, and unleashed an unprecedented growth dynamic that has continued, with only minor slowdowns. In the new circumstances for the development of the global economy and the global trade, People Republic of China seems to be a production superpower, able to change the world trade. In many areas it possesses comparative advantages. China may continue their development to specialise in electronics and increasingly in services.

With or without further trade agreements, services will be more traded and trade policies will have to adjust to changes in the organisation of global value change. The question raised is whether the West will see China's rise as an opportunity for cooperation or for conflict. Economic growth is generally more preferable in China to military and extensive expansion. With new investments, a country can transform its position through industrial expansion at home and sustain it through international trade. China is especially sensitive to the advantages of intensive growth and will not wish to disrupt essential economic arrangements that have been crucial to her success.

The integration of China and India into the world trade system may have increase aggregate welfare in the rest of the world by $0,4 \%$ but factor incomes in individual sectors may fall or rise by more than $5 \%$. Dealing with relative wage pressures and needs for structural adjustment due to rising trade integration will thus be important. The benefits from trade libaralization are transmited through several channels like shifting production from low to high locations, relocation of factors of production towards sectors and firms with high productivity and rising incomes due to an increase in market size that supports more specialisation, faster technology diffusion and stronger incentives to invest in non-rival assets.

The former two effects include mostly static from international trade in goods, services and factors of production, while the latter entails dynamic growth effects. Signifi- 
cant static and dynamic efficiency gains, especially for South countries, could be reaped through further multilateral trade liberalization while global welfare gains from regional agreements are much more limited due to trade diversion. While fostering multilateral trade liberalisation has proved difficult in the recent past and regional arrangements have been frequent, the former should remain priority due these larger benefits and despite the practical challenges of seeing through such reforms in a multipolar world. This results are based on the partial multilateral trade liberalization scenario based on multilateral cuts in tariffs $(50 \%)$ and transaction cost $(25 \%)$ realative to basline.

It is important to underline that also fiscal consolidation will require major efforts in several countries. Fiscal pressures will build up in reverce areas over coming decades unless extensive fiscal reforms are pursued. Asia growth could be curbed further by damages from environmental degradation due inter alia to climate change, wich are likely to affect these country earlier than expected. By 2060, environmental damages in South and South East Asia may lower GDP by more than $5 \%$.

\section{Conclusion}

The trade policy plays a key role in the maintenance of both economic and political liberalization. The prominence of rent seeking in a country can have far-reaching implication for its economic development. Both structural and micro-political economy analyses of foreign trade policy have missed the impact of changing ideas about protectionism and relatively unchanging institutions designed to handle domestic producer complaints. The political consensus on the supply of trade policy and protectionism has changed over time. In the economic depression protectionism played important roles in the politics of political parties. In a global financial and economic crisis and COVID-19 started to prevail also protectionist tendencies which accompany economic recession. Weakened has the same time, the impact of multilateral trade agreements on the processes of liberalisation of international trade in the framework of the WTO and increased the importance of bilateral agreements and regional agreements. This point of view is very important for the theory and practice of the contemporary international business.

The need for firms to organize their supply chains across different countries has led to a demand for regional agreements that cover more than preferential tariffs. The harmonization of standards and rules on investment, intellectual property and services has become a standard part of new trade agreements. The differences among firms involved in trade are also important for the future development. The picture that arises from the trade is that even if many firms are indirectly involved in trade-related activities, only relatively few are exporting or importing and these firms tend to be larger and more productive than others. Such firms also have a role in technology advancement and the diffusion of know-how through supply chains.

Curerent trends in world economy and global politics provide evidence that emerging markets have now arrived to the world economy at last, bringing with it new patterns of uneven development, inequality and injustice. Its newly confident elites, now fully engaged in global circuits of trade, investment and finance, and in global governance too, appear to have left behind their previous role. It is clear that the emerging economies, 
has sufferd less and recoverd more quickly. In addition, it now seems that the patterns of political impact not in the sense of immediate crisis measures but of long-term very big shifs may be equally significant and unexpected.

\section{Bibliography}

Alt J. E., Gilligan M. J. (1994), The Political Economy of Trading States, "Journal of Political Philosophy", no. 2, pp. 165-192.

Alt J. E., Frieden J., Gilligan M. J., Rodrik D., Rogowski R. (1996), The Political Economy of International Trade: Enduring Puzzles and an Agenda for Inquiry, "Comparative Political Studies" 29, pp. 689-717.

Anderson K. (1997), Environmental Standards and International Trade, in: Annual World Bank Conference an Development Economics 1996, eds. M. Bruno, B. Pleskovic, The World Bank, Washington D.C., January, 319.

Anderson K. (1995), Lobbying Incentives and the Pattern of Protection in Rich and Poor Countries, "Economic Development and Cultural Change" 43, pp. 401-423.

Angus Maddison, The World Economy: Historical Statistics, OECD, http://www.china-mike.com/ facts-about-china/economy-investment-business-statistics/, 11.10.2013.

Angus Maddison, University of Groningen: The Economist http://www.china-mike.com/facts-aboutchina/economy-investment-business-statistics/, 11.10.2013.

Aslund A. (2002), Building Capitalism: The Transformation of the Former Soviet Bloc, Cambridge Iniversity Press, Cambridge.

Banerji A., Ghanem H. (1997), Does the Type of Political Regime Matter for Trade and Labour Market Policies?, The "World Bank Economic Review", vol. 11, January 1, 173.

Bhagwati J. N., Srinivisan T. N. (1996), Trade and the Environment: Does Environmental Diversity Detract from the Case for Free Trade?, in: Fair Trade and Harmonization: Prerequisites for Free Trade?, eds. J. N. Bhagwati, R. E. Hudec, M IT Press, Cambridge, Mass..

Busch M. L., Reinhard E. (1999), Industrial Locations and Protection: The Political and Economic Geography of U.S. Nontariff Barriers, "American Journal of Political Science” 43, pp. 1028-1050.

Busch M. L., Reinhard E. (2000), Geography, International Trade, and Political Mobilization in U.S. Industries, "American Journal of Political Science" 44, pp. 703-719.

Caughlin C. C., Chrystal K. A., Wood G. E. (1995), Protectionist Trade Policies: A Survey of Theory, Evidence, and Rationale, in: International Political Economy: Perspectives on Global Power and Wealth, eds. J. A. Frieden, D. A. Lake, $3^{\text {rd }}$ edition, St Martin's Press, New York.

CEIC: Keywise Capital Management, http://www.china-mike.com/facts-about-china/economy-investment-business-statistics/, 11.10.2013.

Chichilnisky G. (1994), North South Trade and the Global Environment, "American Economic Review", 84 (4), pp. 831-874.

China is richer, but most Chinese are still poor (2011), "Fortune", Feb. 17.

China Passes Japan as Second-Largest Economy (2010), "New York Times”, August 15.

China Statistical Yearbook (2010).

China Surges in Americans' Views of Top World Economy (2011), "Gallup's annual World Affairs survey”, Feb., http://www.china-mike.com/facts-about-china/economy-investment-business-statistics/, 11.10.2013.

China vows tougher punishments for copyright piracy (2011), "Reuters”, January, 10.

China's Currency Reserves Rise to Record, Domestic Lending Exceeds Target (2011), "Bloomberg”, Jan. 11. 
China's customs office, the Federation of German Wholesale and Foreign Trade (2010), "New York Times", January 10.

Chow G. C. (2015), China's Economic Transformation, Third Edition, WILEY Blackwell, Maledn (USA)-Oxford (UK).

CIA-The World Factbook, China 2006, www.cia.gov/cia/.

CIA World Fact Book (2011).

Coleman W. D. (1998), From Protected Development to Market Liberalism. Paradigm Change in Agriculture, "Journal of European Public Policy", 5, pp. 632-651.

Containerisation International, http://www.china-mike.com/facts-about-china/economy-investment-business-statistics/, 11.10.2013.

Copland B. R., Taylor M. S. (1995), Trade and Transboundary Pollution, "American Economic Review", 85 (4), pp. 713-737.

Corden W. M. (1996), The Environment and Trade Policy, in: Trade Policy and Economic Welfare, ed. W. M. Corden, Clarendon Press, Oxford.

Devarajan S., Ghanem H., Thierfelder K. (1997), Economic Reform and Labor Unions: A General Equilibrium Analysis Applied to Bangladesh and Indonesia, "The World Bank Economic Review", vol. 11, January, no. 1, pp. 145-170.

Eagleton-Pierce M. (2013), Symbolic Power in the World Trade Organization, Oxford University Press, Oxford.

Esty D. C. (2000), Environment and the Trading System: Picking up the Post-Seattle Pieces, in: The WTO after Seattle, ed. J. J. Schott, Institut for International Economics, Washington, DC, pp. 250-251.

Esty D. C. (1998), NGOs at the World Trade Organisation: Cooperation, Competition, or Exclusion, "Journal of International Economic Law", 1, no. 1, p. 123.

Facts about China: Economy \& GDP 2011-2012, http://www.china-mike.com/facts-about-china/economy-investment-business-statistics/, 11.10.2013.

Fields G. (1994), Changing Labor Market Conditions and Economic Development in Hong Kong, Singapore and Taiwan, Cornell University, Ithaca-New York, Processed.

Foray D., Freeman C. (1993), Technology and the Wealth of Nations: The Dynamics of Constructed Advantage, Pinter, London.

Foreign Direct Investment (2011), "The Economist”, Jan. 20.

Freeman C. (1987), Technology Policy and Economic Performance: Lessons from Japan, Pinter, London.

Freeman C. (1988), Japan, a New System of Innovation, in: Technical Change and Economic Theory, eds. G. Dosi, C. Freeman, R. R. Nelson, G. Silverberg, L. Soete, Pinter, London, pp. 31-54.

Freeman R. (1993), Does Suppression of Labor Contribute to Economic Success? Labor Relations and Markets in East Asia. Harvard University, London School of Economics, Cambridge, Mass.London, Processed.

Frey B. S. (1984), The public Choice View of International Political Economy, "International Organization" 38, pp. 199-223.

Frey B. S., Pommerehne W., Schneider F., Gilbert G. (1984), Consensus and Disconsensus among Economists: An Empirical Inquiry, “American Economic Review” 74, pp. 986-994.

Frieden J. (1991), Debt, Development and Democracy, Princeton University Press, Princeton.

Frieden J., Rogowski R. (1996), The Impact of International Economy on National Policies: An Intellectual Overview, in: Internationalization and Domestic Politics, eds. R. O. Keohane, H. V. Milner, Cambridge University Press, Cambridge.

Gallup's annual World Affairs survey (2011), "China Surges in Americans' Views of Top World Economy", Feb. 
Goldman Sachs Global ECS Research, Dec. 2010

Goldstein J. (1989), The Impact of Ideas on Trade Policy: The Origins of U.S. Agricultural and Manufacturing Policies, "International Organization" 43, pp. 31-71.

Goldstein J. (1995), Ideas, Institutions and American Trade Policy, in: International Political Economy: Perspectives on Global Power and Wealth, eds. J. A. Frieden, D. A. Lake, $3^{\text {rd }}$ edition, New York: St Martin,s Press.

Jackson R. J. (2013), Global Politics in the $21^{\text {st }}$ Century, Cambridge University Press, New York.

Grossman G., Helpman E. (1994), Protection for Sale, “American Economic Review”, 84 (4).

Hadenius A., Teorell J. (2007), Pathways from Authoritarianism, "Journal of Democracy" 18 (1), pp. $145-156$.

Hankla Ch. R. (2006), Party Strength and International Trade: A Cross National Analysis, "Comparative Political Studies" 39 (9), pp. 1133-1156.

Hankla Ch. R., Kuthy D. (2013), Economic Liberalism in Illiberal Regimes Authoritarian Variation and the Political Economy of Trade, "International Studies Quarterly, A Journal of the International Studies Association”, vol. 57, no. 3, September, pp. 492-504.

Helliwel J. F. (1992), Empirical Linkages between Democracy and Economic Growth, Working Paper 4066. National Bureau of Economic Research, Cambridge, Mass., Processed.

In China, Even Crooks Get Ripped Off (2011), China facts: Weird \& Oddbal.

In China, Tentative Steps Toward Global Currency (2011), "New York Times”, Feb. 10.

Jackson R. J. (2013), Global Politics in the $21^{\text {st }}$ Century, Cambridge University Press, New York.

Jones K. (2015), Reconstructing the World Trade Organization for $21^{\text {st }}$ Century, An Institutional Approach, Oxford University Press, Oxford-New York.

Kennedy R. (2007), Fragments of Economic Accountability and Trade Policy, "Foreign Policy Analysis" 3, pp. 145-169.

Kirshner O. (2013), American Trade Politics and the Triumph of Globalism, Routledge Taylore\&Francis Group, New York-London

Kitschelt H., Mansfeldova Z., Markowski R., Toka G. (1999), Post-Communist Party System: Competition, Representation, and Inter-Party Cooperation, Cambridge University Press, Cambridge.

Kleinberg K. B., Fordham B. O. (2013), The Domestic Politics of Trade and Conflict, "International Studies Quarterly, A Journal of the International Studies Association”, vol. 57, no. 3, September, pp. 605-619.

Kleinberg K. B., Fordham B. O. (2010), Trade and Foreign Policy Attitudes, "Journal of Conflict Resolution" 54 (5), pp. 687-914.

Krasner S. D. (1976), State Power and the Structure of International Trade, "World Politics" 28, pp. 317-347.

Krist W. (2013), Globalization and America's Trade Agreements, John Hopkins University Press, Baltimore.

Kugler J. (2006), The Asian Ascent: Opportunity for Peace or Precondition for War?, "International Studies Perspectives, A Journal of the International Studies Association”, vol. 7, no. 1, February.

LaFleur R. (2010), China: Asia in Focus, http://www.china-mike.com/facts-about-china/economy-investment-business-statistics/, 11.10.2013.

Magee S. P., Brock W. A., Young L. Black (1989), Hole Tariffs and Endogenous Policy Theory Political Economy in Genaral Equilibrium, Cambridge University Press, Cambridge.

McDonald's, The Economist, http://www.china-mike.com/facts-about-china/economy-investmentbusiness-statistics/, 11.10.2013.

Milner H. V. (1995), Resisting the Protectionism Temtation: Industry and the Making of Trade Policy in France and the United States during the 1970s, in: International Political Economy: Per- 
spectives on Global Power and Wealth, eds. J. A. Frieden, D. A. Lake, $3^{\text {rd }}$ edition, St Martin's Press, New York.

Milner H. V., Yoffie D. B. (1989), Between Free Trade and Protectionism: Strategic Trade Policy and a Theory of Corporate Trade Demands, "International Organization" 43, pp. 239-272.

Murphy K. M., Shleifer A., Vishny R. W. (1993), Why is Rent-Seeking so Costly to Growth?, "The American Economic Review" 83, pp. 409-414.

Nau H. R. (1989), Domestic Trade Politics and the Uruguay Round: An Overview, in: Domestic Trade Politics and the Uruguay Round, ed. H. R. Nau, Columbia University Press, New York.

Nelson D. (1988), Endogenous Tariff Theory: A Critical Review, “American Journal of Political Science" 32, pp. 796-837.

Nielson D. L. (2003), Supplying Trade Reform: Political Institutions and Liberalization in Middle-Income Presidetial Democracies, "American Journal of Political Science” 47, pp. 470-491.

Olson M. (1985), Space, Agriculture and Organization, "American Journal of Agricultural Economics" 67, PP. 928-937.

Olson M. (1986), The Exploitation and Subsidization of Agriculture in Developing and Developed Countries, in: Agriculture in a Turbulent World Economy, eds. A. Maunder, U. Renborg, Gower, U.K. Aldershot.

Pekkanen S. M., Solis M., Katada S. N. (2007), Trading Gains for Contro: International Forums and Japanese Economic Diplomacy, "International Studies Quarterly" 51, pp. 945-970.

Pepinsky T. B. (2008), Capital Mobility and Coalitional Politics: Authoritarian Regimesand Adjustment in Southeast Asia, "World Politics" 60, pp. 438-474.

Radice H. (2015), Global Capitalism. Selected essays, Routledge, Tylor \& Francis Group, LondonNew York.

Ravenhill J. (ed.) (2014), Global Political Economy, Oxford University Press, Oxford.

"Rediff Business online", 2010, November, http://www.china-mike.com/facts-about-china/economy-investment-business-statistics/, 11.10.2013.

Reuvid J. (2008), Business Insights-China, Kogan Page, London-Philadelphia.

Rodrik D. (1995), Political Economy of Trade Policy, in: Handbook of International Economics, eds. G. Grossman, K. Rogoff, vol. 3, Elsevier Science, Amsterdam.

Rogowski R. (1989), Commerce and Coalitions, Princeton University Press, Princeton, NJ.

Rogowski R. (1987), Political Cleavages and Changig Exposures to Trade, "American Political Science Review" 81, pp. 1121-1137.

Rogowski R. (1987), Trade and the Variety of Democratic Institutions, "International Organization" 41, pp. 203-222.

Rosecrance R. (2006), Power and International Relations: The Rise of China and Its Effects, "Internationl Studies Perspectives, A Journal of the International Studies Association", vol. 7, no. 1, February.

Schattschneider E. E. (1935), Politics, Pressure and the Tariff, Prentice Hall, New York.

Sheingate A. D. (2001), The Rise of Agricultureal Welfare State: Institutions and Interests Group Power in the United States, France, and Japan, Princeton University Press, Princeton, NJ.

Tammen R. J., Kugler J., Lemke D., Stam A., Abdollahian M., Al-Sharabati C., Efird B., Organski A. F. K. (2000), Power Transition, Chatham House, New York.

Thies C. G., Porche S. (2007), Crawfish Tails: A Curious Tale of Foreign Trade Policy Making, "Foreign Policy Analysis" 3, pp. 171-187.

Top 10 largest economies in 2020 (2010), "Euromonitor International”, July 7, http://www.china-mike. com/facts-about-china/economy-investment-business-statistics/, 11.10.2013.

"The Economist", http://www.china-mike.com/facts-about-china/economy-investment-business-statistics/, 11.10.2013. 
The World Factbook (2010), 11.09.2010.

World Bank: CIA Factbook (2010), http://www.china-mike.com/facts-about-china/economy-investment-business-statistics/, 11.10.2013.

World Bank; International Monetary Fund (2013), http://www.china-mike.com/facts-about-china/ economy-investment-business-statistics/, 11.10.2013.

Wright J. (2008a), Do Authoritarian Institutions Constrain? How Legislaturees Affect Economic Growth and Investment, "American Journal of Political Science", 52 (2), pp. 322-343.

Wright J. (2008b), Insurance or Investment? How Authoritarian Time Horizons Impact Foreign Aid Effectiveness, "Comparative Political Studies" 41 (7), pp. 971-1000.

Trading Places (2010), "The Economist” online, August 24.

United Nations report (2010), July,

UNCTAD (2013), http://www.china-mike.com/facts-about-china/economy-investment-business-statistics/, 11.10.2013.

UNCTAD (2013), Multinational Enterprises and the Global Economy by J. H. Dunning, http://www. china-mike.com/facts-about-china/economy-investment-business-statistics/, 11.10.2013.

U.S. Customs \& Border Protection (2010).

\section{Współpraca handlowa w świetle sil modyfikujących współczesny biznes międzynarodowy}

\section{Streszczenie}

W tej pracy badawczej, autor koncentruje się na analizie współpracy handlowej w świetle sił, które są obecnie re-shaping międzynarodowego biznesu. Zgodnie $\mathrm{z}$ teorią polityki handlu zagranicznego dalsza liberalizacja handlu i ulepszone polityki ramowe zwiększyłyby handel i promowałyby wzrost. Należy podkreślić, że otwartość na handel wiąże się z wyższymi dochodami i wzrostem, dlatego też istnieje potrzeba nowych podejść do współpracy handlowej. Tym, co wskazuje na znaczenie i innowacyjność badań, jest przedstawienie nowych modeli polityki handlu zagranicznego i interesów handlowych. Należy przede wszystkim podkreślić, że w nowych ujęciach teoretycznych w zapotrzebowaniu na politykę handlową bardzo ważne są czynniki specyficzne. Niska specyficzność czynników oznacza, że zwroty czynników są wyrównywane przez gospodarkę regionu. Z drugiej strony niektóre czynniki utknęły w swoich dotychczasowych zastosowaniach, dlatego w takim przypadku zwroty czynników produkcji nie są wyrównywane przez gospodarkę regionu, ale są specyficzne dla danego przemysłu. Głównym celem zadania badawczego jest wszechstronna analiza aktualnych tendencji w teorii i polityce handlu zagranicznego, a w szczególności modeli polityki handlu zagranicznego, interesów handlowych określanych przez orientację eksportową i wrażliwość importową, polityki handlu zagranicznego w różnych typach reżimów autorytarnych, presji protekcjonistycznych w różnych systemach politycznych, poziomu presji protekcjonistycznych, zróżnicowania polityki handlu zagranicznego między państwami, liberalizacji polityki handlu zagranicznego Chin i jej skutków, tendencji do liberalizacji handlu międzynarodowego i problemu ochrony środowiska oraz tendencji do bilateralizmu w polityce handlu zagranicznego. Należy podkreślić, że wolny handel sam w sobie nie jest odpowiedzialny za wzrost gospodarczy, ważniejsze są natomiast czynniki decydujące o stabilności makroekonomicznej oraz zwiększające inwestycje.

Słowa kluczowe: polityka handlu zagranicznego, wybór publiczny, liberalizm, protekcjonizm, reżimy autorytarne, bilateralizm

Article submitted: 18.10.2021; article accepted: 12.11.2021. 